Ege Eğitim Dergisi 2014 (15) 1: 45-79

\title{
5E Öğrenme Modeli’ne Göre Düzenlenmiş Eğitim Durumlarının Bilimsel Süreç Becerilerine Etkisi*
}

\section{Cemal BIYIKLI ${ }^{* *} \quad$ Esed YAĞCI***}

\section{$\ddot{\mathbf{O} z}$}

Bu çalışmada, 5E Öğrenme Modeli'ne göre düzenlenmiş dördüncü sınıf Fen ve Teknoloji dersi eğitim durumlarının öğrencilerin bilimsel süreç becerilerine etkisinin belirlenmesi amaçlanmıştır. Araştırmada, kontrol gruplu öntestsontest deneysel desen kullanılmıştır. Değişkenleri karşılaştırmak için kovaryans analizi kullanılmıştır. Sontestten üç ay sonra da kalıcılık testleri uygulanmıştır. Çalışma, özel bir ilköğretim okulunun 4. Sınıf Fen ve Teknoloji dersi kapsamında yürütülmüştür. Denel işlem 18 hafta sürmüştür. 2011-2012 öğretim yılında bu dersi alan $4 \mathrm{~A}$ ve $4 \mathrm{E}$ sınıfı öğrencileri çalışmanın denekleri olarak belirlenmiştir. Deney grubunda 5E Öğrenme Modeli'ne göre düzenlenmiş öğretim uygulanmıştır. Kontrol grubunda ise mevcut programa ait eğitim durumları sürdürülmüştür. Çalışmada, kontrol grubu ile deney grubu arasında bilimsel süreç becerileri açısından deney grubu lehine anlamlı fark olduğu belirlenmiştir.

Anahtar kelimeler: 5e öğrenme modeli, bilimsel süreç becerileri, fen ve teknoloji dersi.

\footnotetext{
* Bu makale yazarın, Hacettepe Üniversitesi Sosyal Bilimler Enstitüsü Eğitim Programları ve Öğretim Bilim Dalında hazırlamış olduğu "5E Öğrenme Modeline Göre Düzenlenmiş Eğitim Durumlarının Bilimsel Süreç Becerileri, Öğrenme Düzeyi ve Tutuma Etkisi” başlıklı doktora tezinin bir bölümünden özetlenmiştir.

** Dr., Ankara Özel Tevfik Fikret Okulları, cbiyikli@ yahoo.com

*** Yrd.Doç.Dr., Hacettepe Üniversitesi, esed@ hacettepe.edu.tr
} 


\title{
The Effect of 5e Learning Model Designed According to Learning Experiences on The Science Process Skills
}

\begin{abstract}
In this study, it was aimed to determine the effect of teaching activities of $4^{\text {th }}$ grade students in Science and Technology Course, designed according to 5e Learning Model, on students' science process skills. In this research, a pre-test post-test control group experimental design to compare the dependent variables covariance analysis were used. The retention tests were also administered after three months the post-test. The study was carried out for 18 weeks in the "Fourth Grade Science and Technology" course in a private elementary school. The students at $4 \mathrm{~A}$ and $4 \mathrm{E}$ Cohorts, who took this course in the 2011-2012 academic years constituted the samples of the study. The 5e Learning Model instructional design was implemented in the experimental group while traditional teaching methods and activities were carried out in the control group. Consequently the study showed, that there is a significantly difference between the control and experimental groups about students' science process skills in favour of the experimental group.
\end{abstract}

Key words: 5e learning model, science process skills, science and technology course. 


\section{Giriş}

Bilimsel ve teknolojik gelişmeler bir taraftan insan yaşamını kolaylaştırsa da diğer taraftan insanoğlu her geçen gün daha karmaşık ve zor problemlerle yüzleşmek ve baş etmek zorunda kalmaktadır. Bu gelişmelerin önemli bir sonucu olarak bireyler; mesleki, sosyal ve kişisel gelişimlerini yaşamları boyunca devam ettirmekle sorumludur. Bireylerin bu süreçte bilimsel düşünme gücüne sahip olma ve bunları yaşamlarına aktarabilme gerekliliği, eğitimcilerinde bunu sağlayabilecek açılımlara yönelmesini zorunlu kılmıştır. Bu yönelme bilimsel okuryazarlı̆̆ın ya da bilimsel kültürün öğrenilmesine ilişkin çabaların tetikleyicisi olarak da düşünülebilir.

Öğretme-öğrenme sürecini öğrencilerin bilimsel düşünme sürecini ortaya koymalarını sağlayacak biçimde yapılandırmak ve bununla birlikte bilginin yeni durumlara transfer edilmesini sağlamak için 5E Öğrenme Modeli'nin kullanılması yetişeğin tüm öğelerini de etkileyecek bir hareket olarak düşünülebilir. Böylesi bir öğretim sürecinde yetişeğin hedefler, içerik, öğretmeöğrenme süreçleri ile ölçme ve değerlendirme öğeleri göz önüne alınmalıdır. (Campbell, 2006). Bir başka değişle yetişek, özellikle bilimsel süreç becerilerine odaklanan, öğrencinin yaparak ve yaşayarak öğrenmesini sağlayabilecek ve öğrenmeleri hem süreçte hem de süreç sonunda değerlendirerek öğrencinin öğrenme sürecine ışık tutacak bir yapı ile tasarlanmalıdır.

5E Öğrenme Modeli, yapılandırmacı öğrenme anlayışına dayanması, bilimsel süreç becerilerine odaklanması ve yetişekte problem çözme boyutunu vurgulaması (Öztürk, 2008) nedeniyle, öğretimin düzenlenmesi ve yetişeğin tasarlanması için bir yol haritası görevi üstlenmektedir. $\mathrm{Bu}$ model kullanıldığında öğrenci; konuya odaklanır, bilgiyi keşfeder, organize edip sinuflar, yeni durumlara uygular, kavramsallaştırır (Bybee, 1997). Bu beceriler öğrencinin hem ön deneyimleri, hem sinff etkinlikleri hem de çevreyle etkileşimleri sonucu oluşur.

5E Öğrenme Modeli, 1970'li yıllardaki Biyoloji Bilimi Program Çalışmaları (The Biological Science Curriculum Study-BSCS) grubunun yönetici araştırmacisı Roger Bybee tarafından geliştirilmiştir. 5E modeli: Dikkat Çekme, Ön Öğrenmeleri Ortaya Çıkarma, Öğrenme Etkinliğine Girme (Engage), Araştırma, Keşfetme (Explore), Açıklama (Explain), Transfer Etme, Derinleşme (Elaborate), Değerlendirme (Evaluate) aşamalarından oluşmaktadır. Aşamalar Tablo 1'de açıklanmıştır. 
Tablo 1.

5E Öğrenme Modeli Aşamaları (Devam)

\begin{tabular}{ll}
\hline Modelin Aşamaları & Aşamaların Açıklaması \\
\hline Dikkat Çekme, Ön & Bir olay, durum ya da problemden hareketle \\
Öğrenmeleri Ortaya Çıarma, & öğrencilerin ilgileri ve meraklarının çekilmesi \\
Öğrenme Etkinliğine Girme & beklenir. Önceki bilgiler ve gelecekteki \\
(Engage) & $\begin{array}{l}\text { öğrenilecek kavramlar arasında ilişki kurulur. } \\
\text { (Bybee, 1997). }\end{array}$
\end{tabular}

\author{
Araştırma, Keşfetme \\ (Explore)
}

\section{Açıklama \\ (Explain)}

Öğrenciler düşüncelerini ortaya koymak için araştırmalar yapar. Yapılan araştırmalar modelin ilk aşamasındaki soruya ya da sorulara yanıt olabilir. Araştırmalar, modelin temelini oluşturur (Bybee, Taylor, Gardner, Van Scotter, Powell, Westbrook ve Landes, 2006). Öğretmen bu aşamada gruplara tartışmaları için sorular sorar ve onlara rehberlik eder. Öğretmen öğrencilerin kendi düşüncelerini ortaya koyabilecekleri, onların ihtiyaç duyduğu zaman ve materyalleri temin eder (Bybee 1997; Bybee ve diğerleri, 2006).

Öğrenciler kavramlarla ilgili elde ettikleri bilgileri ya da süreçte geçirdikleri yaşantıları açıklar. Öğretmen bu aşamada çeşitli yöntem ve teknikleri ihtiyacına göre kullanıp süreçteki açıklamaların zenginleşmesini sağlar (Bybee ve diğerleri, 2006). Açıklama kısmı, modelin en kısa aşamasıdır. Çünkü bundan sonra gelen transfer etme/derinleşme aşaması öğrencilerin bilgilerini yapılandırmalarını ve kavramları biraz daha genişletmelerini içerir (Trowbridge, Bybee ve Powel, 2004).

Önceki üç aşamada geçirilen yaşantılara ve elde edilen bilgilere dayanır. Öğrenciler elde 
5E Öğrenme Modeli'ne Göre Düzenlenmiş Eğitim Durumlarının Bilimsel Süreç Becerilerine Etkisi

Transfer Etme, Derinleşme

(Elaborate)

Değerlendirme

(Evaluation)

ettikleri bilgiler yardımıla kavramları yeni

durumlara transfer eder. Bybee göre, $(1997 ; 181)$ bu aşamanın en önemli amacı: "Sürecin, becerilerin ve kavramlarm genelleştirilmesidir." Transfer/derinleşme aşaması öğrencilere kavram yanılgılarını düzeltmeleri ve anlamlarını güçlendirmesi için önemli fırsatlar verir (Bybee ve diğerleri, 2006).

Öğrencilerin anlama düzeyi bu aşamada belirlenir (Bybee ve diğerleri, 2006). 5E modeli içerisinde değerlendirme aşaması, süreç sonunda öğrenme ürünlerini kontrol etmek açısından dikkat edilmesi gereken bir aşamadır; fakat gözden kaçırılmaması gereken nokta, 5E modeli kullanılırken değerlendirmenin, her aşama sonunda gözlemlerle, öğrenci katılımlarının niteliklerinin kontrolü ile sağlanması gerekir (Öztürk, 2008).

Modelde yer alan aşamalar, öğretmene eğitim ortamında bulunması gereken öğelerle ilgili bir fikir verir. Modeldeki basamakların sıraları değişebilir. Öğretmen, bir fikri iddia edip sıkı sıkıya basamaklara bağlı kalır, dersi aşırı derecede yapılandırırsa, dersin doğal akıcılığından uzaklaşır. Bu tarz bir anlayış yapılandırmacılığın ortaya çıkış gerekçesine ters düşer (Senemoğlu, 2009).

5E modelinde öğrenci öğrenmenin merkezindedir. Öğrenci, yapılandırmacı rolü üstlenirken sürecin ya da konunun özünü anlaması ve bütünleştirmesi için deneysel kanıt ve öğrenmenin önemini de kabul eder (Tinker, 1997). Yapılandırmacı sınıf ortamında öğrenciler hipotez oluşturmaya ve bu hipotezleri kontrol etmeye yönlendirilirler. Böylelikle öğrenciler bu yolla öğrendiklerini başka bir problemin çözümünde de uygulayabilme becerisi kazanurlar (Smerdon, Burkam ve Lee, 1999).

Yapılandırmacı öğretme-öğrenme süreçlerinin bu özelliği, 2005 yılında uygulamaya giren yeni fen bilimleri programında da sıkça söz edilen bilimsel süreç becerilerinin kazandırılma amacıyla uyumlu görünmektedir (MEB, 2005). Bilimsel süreç becerilerinin öğrencilere kazandırılması ile öğrencinin hem 
öğrenmeyi öğrenmesi, hem de yeni karşılaştı̆̆ bir sorunda onu çözmek için nasıl bir yol izlemesi gerektiğinin de farkında olması açısından önemlidir.

Gagne (1965), bilimsel süreç becerilerini, problem çözerken ya da deney yaparken, doğru bilimsel davranışları yansıtma, bütün bilim alanlarına uygun, transfer edilebilir yetenekler takımı olarak tanımlamıştır (Akt. Ewers, 2001). Abruscato'ya (2000) göre, bilim adamlarının yaptıkları buluşlar, onların bilimsel süreç becerileri olarak bilinen, çok farklı fakat çok önemli bir grup beceriyi kullanmadaki yeteneğinden gelir. Martin'e (2006) göre bilimsel süreç becerileri, bilim adamlarının bilimsel süreçle bir sorun ortaya koyduklarında kullandıkları yöntemlerdir. Bilimsel süreç becerileri transfer edilebilir yetenek olup birçok bilim alanında uygulanabilir, bilim adamlarının davranışlarını yansıtabilir. Bilimde düşünme yolları, süreç becerileri olarak adlandırılır. Bilim adamları veya öğrenciler, bilimle uğraşırken yorum yapma, sınıflandırma, hipotez kurma ve deney yapma gibi düşünme becerilerini kullanırlar (Rezba, Sprague, McDonnough ve Matkins, 2007).

Çeşitli araştırmacılar ve programların belirttiği bilimsel süreç becerilerinin hepsinde ortak olan alt beceriler bu çalışmadaki bilimsel süreç becerilerini oluşturmuştur. Bu beceriler, Tablo 2'de açıklanmıştır.

Tablo 2.

Bilimsel Süreç Becerileri

\section{Bilimsel Süreç Becerilerin Açıklaması \\ Becerileri}

Gözlem

Obje ve olaylar hakkında duyu organları yardımıla bilgi

toplamaktır. Örneğin, kalem kırmızıdır gibi. (Ostlund, 1992;

Gabel, 1993; Smith, 1997; Abruscato, 2000; Lancour, 2005;

Harlen, 2007; Rezba, Sprague, Mc Donnough, Matkins, 2007;

Valentino, 2000).

Standart ya da standart olmayan ölçme araçları ile obje ve olayları betimlemek için ölçüm yapmaktır (Lancour, 2005; Ostlund, 1992; Smith, 1997;). Örneğin, 1 metre ile bir uzunluğun ölçülmesi gibi.

Sınıflandırma Sınıflandırma, obje ve olayları belirli özelliklerine göre gruplama ya da siralamaktır (Lancour, 2005; Ostlund, 1992; Smith, 1997; Valentino, 2006). 


\begin{tabular}{|c|c|}
\hline $\begin{array}{l}\text { Çıkarım } \\
\text { Yapma }\end{array}$ & $\begin{array}{l}\text { Gözlemlerden elde ettiğimiz sonuçların mantıksal olarak } \\
\text { kullanılmasıdır. Gözlem duyulardan biriyle elde edilen } \\
\text { verilerin açıklanmasıyken çıkarım gözlemlerle oluşan } \\
\text { düşüncelerin açıklanmasıdır (Abruscato, 2000; Bell, 2008). }\end{array}$ \\
\hline $\mathbf{a}_{1}$ & $\begin{array}{l}\text { Kanıtlar göstererek gelecekte olacaklar hakkında bir şeyler } \\
\text { söylemektir. Bir bitkinin önceki dört haftadaki gelişimini } \\
\text { dikkate alarak gelecekte } 3 \text { haftada büyümesinin nasıl } \\
\text { olacağını söylemek gibi (Lancour, 2005; Smith, 1997). }\end{array}$ \\
\hline
\end{tabular}

Bilimsel

Yapılan açıklamaların fen bilimlerine ait terminolojiye uygun İletişim Kurma yapilmasidir (Abruscato, 2000).

Değişkenleri Belirleme ve Kontrol Etme

Hipotez Kurma ve

Test Etme

Deney Yapma
Değişken, değişebilir bir nitelik ya da nesnedir (Abruscato, 2000). Bir hipotez ya da çıkarım test edilmeye ihtiyaç duyulabilir. Bunun için değişkenlerin tanımlanması ve kontrol edilmesi gerekir (Gabel, 1993).

Öğrencilerin bilimsel etkinlikleri sırasında "kesin olmayan açıklama önerileri" olarak tanımlanan bir süreçtir. Hipotez tahmine çok benzer, fakat daha kontrollü ve formaldir. Hipotez, deneyin sonucu hakkında var olan bilgilere dayanarak yapılan "eğitimli tahminler" dir (Anagün ve Yaşar, 2009; Bağcı Kılıç, 2003).

Bilimsel bir gerçeği göstermek, bir doğa yasasını doğrulamak ya da bir olasılığı kanıtlamak için yapılan işlemler zinciridir (Erbağ, Şimşek ve Çınar, 2005). Deneyi yaparak öğrenme etkinliklerinden ayıran iki temel ölçüt vardır. Bunlar; öğrencilerin bir hipotezi test etmeleri ve değişkenleri kontrol etmeleridir (Peters ve Stout, 2006).

Deney ve gözlem sonucunda elde edilen verilerin çizelge, tablo, grafik, resim vb. gibi formlarla ifade edilmesidir (Carin, 1993). Başka bir deyişle toplanan verilerin sistemli bir şekilde 
organize edilmesidir.

Verileri

Yorumlama

\section{İşevuruk}

Tanımlama
Yaratıcı bir süreçtir. Bilim insanının geçmişteki bilgileri onların verileri yorumlamasını etkiler (Bell, 2008). Bu anlamda bakıldığında verileri yorumlama sürecinin önceki öğrenmelerimizden etkilendiğini, kişiden kişiye farklılık gösterip öznel düşünce ürünü olduğunu söyleyebiliriz.

Bilimsel çalışmayı yapan kişilerin tecrübelerinden hareketle yaptıkları tanımlardır (Abruscato, 2000; Gabel, 1993).
Model Oluşturma
Obje, olay ya da düşüncelerin zihinsel ya da fiziksel tasarımını yaratmaktır (Ostlund, 1992; Smith, 1997).

5E Öğrenme Modeliyle ilgili Türkiye'deki araştırmalar incelendiğinde; araştırmalarda daha çok 5E'nin akademik başarı ve tutum üzerindeki etkisinin incelendiği, son yıllarda ise bu iki değişkenin yanına bilimsel süreç becerilerinin de eklendiği görülmektedir. Bu araştırmaların bulguları incelendiğinde, 5E Öğrenme Modeli'nin bilimsel süreç becerilerinin gelişimini (Anagün, 2009; Önal, 2008; Özaydın, 2010; Özsevgeç, 2007; Öztürk, 2008; Sevinç, 2008), akademik başarıyı (Akar, 2003; Anagün, 2009; Aydoğmuş, 2008; Canlı, 2009; Deren, 2008; Erdoğdu, 2001; Ergin, 2006; Gürses, 2006; Önal, 2008; Önder, 2011; Özaydın, 2010; Özsevgeç, 2007; Öztürk, 2008; Sağlam, 2005; Saygın, 2003; Süzen, 2009), tutumu (Anagün, 2009; Deren, 2008; Ergin, 2006 Önal, 2008; Özaydın, 2010; Özsevgeç, 2007; Öztürk, 2008; Sağlam, 2005) anlamlı şekilde etkilediği görülmüştür. Bunun yanı sıra, 5E Öğrenme Modeli'nin tutumu anlamlı şekilde etkilemediğini ortaya koyan araştırmalara da rastlanmıştır (Akar, 2003; Andaç, 2007; Aydoğmuş, 2008; Canlı, 2009; Erdoğdu, 2011; Sevinç, 2008).

Yurtdışındaki alanyazın incelendiğinde, 5E Öğrenme Modeli'nin bilimsel süreç becerilerine etkisinin ele alındığı çalışmalar, akademik başarı ve tutum üzerine yapılan çalışmalara göre daha azdır. Araştırmaların bulguları incelendiğinde, 5E'nin bilimsel süreç becerilerini (Buntod, Suksringam ve Singseevo, 2010), akademik başarıyı (Buntod, Suksringam ve Singseevo, 2010; Chen 2008; Garcia, 2005; McCormick, 2000; Gatlin 1998) ve tutumu (Chen, 2008; Garcia, 2005; McCormick, 2000) anlamlı şekilde etkilediği görülmüştür.

2005 yilında uygulamaya giren yeni fen ve teknoloji programinda:

"Sadece günümüzün bilgi birikimini öğrencilere aktarmayı değil; araştıran, sorgulayan, inceleyen, günlük hayatıyla fen konuları arasında bağlantı kurabilen, hayatın her alanında karşılaştığı problemleri 
çözmede bilimsel yöntemi kullanabilen, dünyaya bir bilim adamının bakış açısıyla bakabilen bireyler yetiştirmeyi amaçlandığını; bu amaçların gerçekleşmesi için programda öğrencilere bilimsel araştırmanın yol ve yöntemlerini benimsetmek amacıyla bilimsel süreç becerileri olarak adlandırılan becerilerin kazandırılması"

öngörülmektedir (MEB, 2005). Bu öngörünün gerçekleşmesine, 5E Öğrenme Modeli'nin bilimsel düşünmeye önem vermesi, süreci bir problem etrafında örgütlemeye çalışması, bilimsel süreç becerilerinde yer alan alt becerilerinin kullanılmasına olanak vermesi gibi özelliklerinden dolayı yardımcı olacağı düşünülmektedir. Bu anlamda 5E Öğrenme Modelin'e uygun bir denel işlem materyalinin oluşturularak uygulanması bu çalışmada önemli görülmektedir.

Yapılandırmacı anlayışın son yıllarda eğitim sistemi üzerindeki etkileri göz önüne alındığında, 5E Öğrenme Modeli'nin, bilimsel süreç becerilerinin öğretiminde işe koşulması da bu araştırmayı önemli kılmaktadır.

Türkiye'de bilimsel süreç becerilerinin performansa dayalı ölçme araçlarıyla belirlenmesine yönelik araştırmalar oldukça azdır. Bu araştırmada, fen ve teknoloji derslerinin önemli bir boyutu olan bilimsel süreç becerilerinin ölçülmesi için, becerilerin göstergelerine uygun performans değerlendirme aracı hazırlanmıştır. Araştırmada hazırlanan performansa dayalı bilimsel süreç becerileri ölçme aracının da alanyazın için önemli olacağı düşünülmektedir. Ayrıca, araştırmada bilimsel süreç becerileri alt becerilerinin her birinin ayrı ayrı deney ve kontrol grubu öğrencileri arasında sontest ve kalıcılık puanları açısından karşılaştırılmasının yapılması da araştırmayı önemli kılmaktadır. Bu noktadan hareketle araştırmada, bilimsel düşünme alışkanlığının kazanılmasına yardımcı olacağı, öğrenilenlerin yeni problemlerin çözümü için kullanılacağı ve en önemlisi yapılandırmacı öğrenme anlayışına uygun olan 5E Öğrenme Modeli'nin işe koşulmasının dördüncü sınıf öğrencilerinin bilimsel süreç becerileri üzerindeki etkisinin incelenmesi amaçlanmaktadır.

Yukarıda sözü edilen gereksinimlere dayalı olarak bu araştırmanın temel amacı, fen ve teknoloji öğretiminin daha nitelikli hale getirilmesi için 5E Öğrenme Modeli'nin bilimsel süreç becerilerine etkisini incelemek olarak belirlenmiştir. Temel amaca bağlı olarak aşağıdaki alt problemler sınanmıştır:

5E Öğrenme Modeli'nin bilimsel süreç becerilerine etkisini incelemek olarak belirlenmiş, temel amaca bağlı olarak aşağıdaki alt problemler sınanmıştır:

5E Öğrenme Modeli'ne göre düzenlenmiş eğitim durumlarının uygulandığ1 deney grubundaki ögrenciler ile mevcut programın uygulandığ öğrencileri arasında;

a) bilimsel süreç becerilerinin gelişim ve kalıcılık düzeyi puanları, 
b) bilimsel süreç becerilerinin alt becerilerine ait test puanları arasında anlamlı bir farklılık var midır?

\section{Yöntem}

Araştırmada, kontrol gruplu öntest-sontest deneysel desen kullanılmıştır. Araştırmanın bağımsız değişkenini 5E Öğrenme Modeli'ne göre düzenlenmiş öğretim programı; bağımlı değişkenini ise bilimsel süreç becerileri oluşturmaktadır.

$\mathrm{Bu}$ çalışmada bilimsel süreç becerilerinin değerlendirilmesinde, öğrencilerin yaptıkları deneyden hareketle gösterdikleri performansa dikkat edilmiştir. Ayrıca, performansın değerlendirileceği deney, öğretim sürecindeki içerikten farklıdır. Bu farklılığın nedeni hem öğretim sürecinde öğrenilen konuların, deneyi (yani değerlendirilecek performansı) etkilemesini azaltacağı hem de becerinin öğretim sürecinde öğretilen bilgiden bağımsız ne kadar gelişip gelişmediği ortaya konulacağını göstermesidir. Bu düşünceden hareketle araştırmada dördüncü sınıf düzeyinde öğrencinin karşılaşmayacağı bir konunun irdelendiği deney seçilmiştir.

\section{Çalışma Grubu}

Çalışma, Ankara Özel Tevfik Fikret İlköğretim Okulu dördüncü sınıf fen ve teknoloji dersinde yürütülmüştür. Okulda beş adet dördüncü sınıf şubesi bulunmaktadır. Yansız atama ile şubelerden biri deney, biri de kontrol grubu olarak seçilmiştir. Deney grubunda 5E Öğrenme Modeli uygulanırken kontrol grubunda aynı derste mevcut uygulanan programın eğitim durumları sürdürülmüştür. Deney grubunda 16 kız ve 14 erkek öğrenci, kontrol grubunda ise 14 kız ve 16 erkek öğrenci bulunmaktadır. İki gruptaki öğrenciler ilk kez fen ve teknoloji dersi görmüşlerdir.

\section{Denel İşlem}

Dördüncü sınıf düzeyinde fen ve teknoloji dersinde öğrencilerin bilişsel, duyuşsal öğrenmeleri; sosyal etkileşimleri; öğretmen ve öğrenci rolleri ile sınıfın fiziksel şartlarını incelemek amacıyla denencel işlemin uygulandığı yılın bir önceki öğretim yılının birinci döneminde Ankara Özel Tevfik Fikret İlköğretim Okulu'nun dördüncü sınıfların iki şubesinde gözlemler yapılmıştır. Gözlemler aralıklarla toplam 30 saat sürmüştür.

Dönem boyunca yapılacak etkinlikler, bu etkinliklerin uygulanacağı ortamlar, süreleri, öğretmen ve öğrencilerin bu etkinliklerdeki görev ve sorumlulukları, kontrol noktaları, süreçte ortaya çıkacak ürünler, ihtiyaç duyulacak kaynak, araç ve gereçler ile destekleyici diğer etkinlikler belirlenmiştir. 
5E Ö̆grenme Modeli'ne göre düzenlenmiş öğretimin uygulanacağı denencel öğretim programı tasarısı 18 haftalık bir zaman dilimine yerleştirilmiştir. Tasarıya ilk önce MEB dördüncü sınıf Fen ve Teknoloji Dersi Öğretim Programındaki kazanımları için öğretme-öğrenme etkinlikleri ve sınama durumları planlanmaya başlanmıştır. Bu etkinlikler eş zamanlı bir çalışma ile planlanmıştır.

Araştırmanın bağımsız değişkeni 5E Öğrenme Modeli'ne dayalı etkinliklerinin yürütülmesi için denencel işlemlerin yapılacağı dördüncü sınıf fen ve teknoloji dersi ilk döneminde yer alan üç ünitenin (Vücudumuzun Bilmecesini Çözelim, Maddeyi Tanıyalım, Kuvvet ve Hareket) etkinlikleri 5E Öğrenme Modeli'ne göre düzenlenmiştir. Dönem boyunca yapılacak etkinlikler, bu etkinliklerin yapılacağı ortamlar, süreleri, öğretmen ve öğrencilerin bu etkinliklerdeki görev ve sorumlulukları, kontrol noktaları, süreçte ortaya çıkacak ürünler, ihtiyaç duyulacak kaynak, araç ve gereçler ile destekleyici diğer etkinlikler belirlenmiştir. Denel işlem ile bilimsel süreç becerilerinin 5E Öğrenme Modeli aracılığıyla gerçekleştirilmesine odaklanılmıştır. Bunun için etkinlikler düzenlenirken modelin içinde bilimsel süreç becerilerinin etkili olması özellikle önemsenmiştir. Sınama durumlarının planlanmasında ise ürüne ve sürece dönük değerlendirme etkinliklerinin bir arada kullanılacağı bir düzenek hazırlanmıştır. Araştırmacı tarafından 5E Öğrenme Modeli'ne göre hazırlanan denencel öğretim programı tasarısı uzmanlarla görüşülerek ve tekrar tekrar gözden geçirilerek son şekli verilmiştir.

Denencel öğretim programı tasarısı, program geliştirme, ölçme ve değerlendirme uzmanları ile alan uzmanlarının görüşüne sunularak öneri ve eleştiriler dikkate alınarak tasarıya son şekli verilmiştir. Öğrencilere ve öğretmene çalışma süresince rehberlik edecek “Çalışma Planı” hazırlanmıştır.

Denencel öğretim programını uygulayacak öğretmen ile görüşülerek çalışma hakkında bilgi verilmiş, incelemeleri için "Çalışma Planı" öğretmene sunulmuştur. Dersin öğretmeni ile daha sonra bir toplantı düzenlenerek çalışmanın genel örüntüsü ve uygulama ilkeleri konusunda bilgilendirme yapılmıştır. Öğretmen eğitimi, deney öncesinde bire-bir öğretimle ve bir haftalık sürede gerçekleştirilmiştir. Denel işlem süresince de bu toplantılara her hafta birer saat yapılarak devam ettirilmiştir.

Deney grubu ile yapılan ilk oturumda öğrencilerin fen ve teknoloji dersi ile ilgili beklentileri, öğrenmek istedikleri, değerlendirme süreci ile ilgili beklenti ve görüşleri tartışılmıştır. Ardından öğrencilere denencel öğretim programı tasarısı tanıtılmış, yapılacak etkinliklerdeki görev ve sorumlulukları açıklanmıştır. Öğrencilerin düşüncelerinin tasarlanan denencel öğretim programındaki unsurlarla örtüşmesi sağlanmıştır. 
Araştırmanın denel işlem sürecinde kullanılacak ölçme araçları ve uygulamalar Şekil 1'de verilmiştir.

Şekil 1. Ölçme Araçları ve Uygulamalar

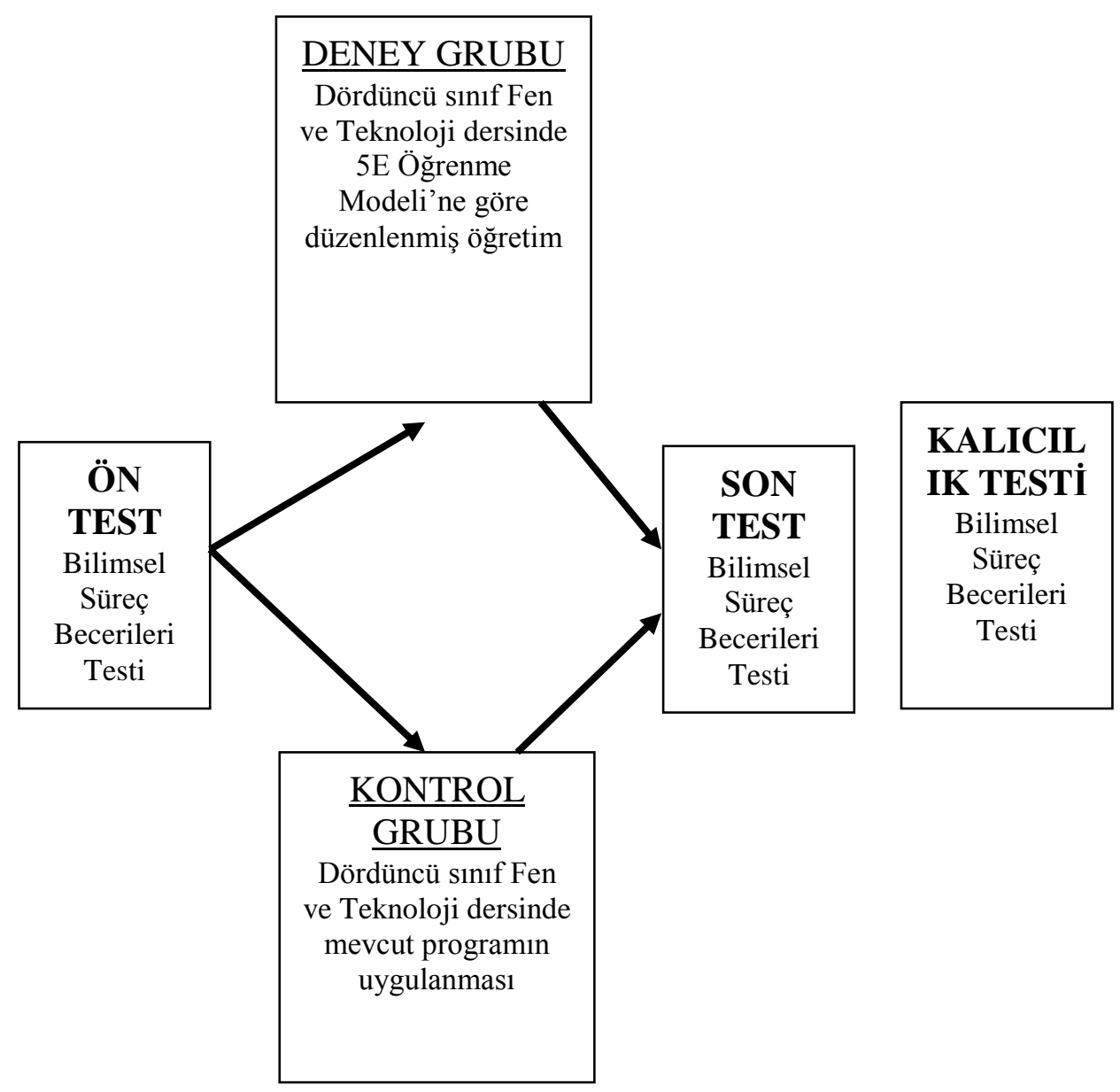

\section{Veri Toplama Araci}

Bilimsel Süreç Becerileri Testi (BSBT), öğrencilerin bilimsel süreç becerilerini ölçmek amacıyla araştırmacı tarafından, bu araştırma kapsamında geliştirilmiş ve deneklere denel işlemin başında, sonunda ve üç aylık bir süre sonunda toplam üç defa uygulanmıştır. 


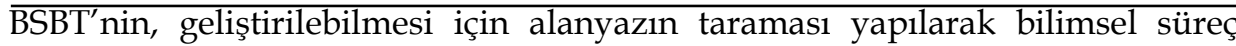
becerileriyle ilgili uygulanan modeller incelenmiştir. Modellerdeki ortak olan bilimsel süreç becerileri belirlenmiştir. Becerilere ait göstergeler hazırlanmış ve her biriyle ilgili kapsam geçerlik oranı ve indeksi hesaplanmıştır. Bu hesaplamalarla seçilen Bilimsel Süreç Becerilerine ait göstergeler, fen bilimlerinde bilimsel süreç becerileriyle ilgili çalışma yapmış sekiz akademisyenin görüşüyle son şeklini almıştır. Ayrıca akademisyenlerin ortak görüşü ile alt becerilere ait kritik göstergeler de belirlenmiştir.

Bilimsel Süreç Becerilerine ait alt becerileri temsil eden her kritik gösterge için en az iki sınama durumu oluşturulmuştur. BSBT'de öğrencilerin deneyde göstermeleri gereken performanslarının yanında, deneyden hareketle yanitlayabilecekleri toplam 19 soruluk bir form da hazırlanmıştır. Performansın değerlendirilmesinde deney yapma becerisi gözlem formu aracılığıla, diğer beceriler ise dereceli puanlama anahtarı ile değerlendirilmiştir.

BSBT'de öğrencilerin verilen malzemeleri kullanarak bireysel olarak iki deney yapması (Deneyde öğrencilerden beklenen performans bir plastik kavonozun içindeki suya tuz atıp onu karıştırarak yumurtayı su dolu kapta yüzdürmeye çalışmasıdır.) beklenmiştir. Deney yapma süreci, iki gözlemci tarafından yarı yapılandırılmış gözlem formu aracılığıyla gözlenerek deney yapma becerisi adına puanlanmıştır. Hipotez kurma ve değişkenleri belirleme becerileri için deneye başlamadan önce öğrencilerin deneyle ilgili hipotez kurması ve değişkenleri belirlemesi istenmiştir. Ölçme becerisi, kavanozdaki suyun deneyin başlangıcında ve sonundaki miktarının cetvelle ölçülüp ölçüm değerinin yazılmasıyla belirlenmiştir. Gözlem becerisi puanı, kavanozdaki suda yumurtanın yükselme sürecinin gözlenip not edilmesiyle elde edilmiştir. Verileri toplama becerisi süreçten elde edilen bilgilerin formlara not edilmesiyle; verileri yorumlama becerisi not edilen bilgilerin yorumlanmasıyla puanlanmıştır. Çıkarım yapma becerisi, deneyden elde edilen sonuçların açıklanmasıyla; sınıflandırma becerisi deneyde kullanılan malzemelerin belirli ölçütler açısından gruplamasıyla; tahmin etme becerisi deneydeki bazı durumların değişmesinde olabileceklerin açıklanmasıyla; işe-vuruk tanımlama deneyde kullanılan tuz sözcüğünün tanımlanmasıyla; model oluşturma deney sürecinin çizilmesiyle; bilimsel iletişim kurma öğrencilerin sınav kağıdına yazdıklarının bilimsel olup olmaması açısından puanlanmıştır.

\section{Verilerin Elde Edilmesi}

Bilimsel Süreç Becerilerine ait hazırlanan deneme formu, Ankara'daki üç ilköğretim okulundaki, dördüncü sınıfta toplam 74 öğrenciye uygulanmıştır. Uygulamalar sınıf ortamında yapılmıştır. Öğrencilerin deney süresince gösterdiği performans 3 gözlemci tarafından yapılandırılmış gözlem formu ile 
puanlanmıştır. Bu puanlar, öğrencilerin bilimsel süreç becerilerinin alt becerisi olan deney yapma becerisi adına değerlendirilmiştir. Üç gözlemcinin öğrencilerin deneyde gösterdikleri performansa verdiği puandan hareketle puanlayıcılar arası güvenirlik hesaplanmıştır. Ayrıca testte yer alan açık uçlu sorular ya da sınama durumları da beş puanlayıcı tarafından puanlanarak her bir madde için puanlayıcılar arası güvenirlik katsayısı belirlenmiştir. Puanlayıcılar arası güvenirliğin hesaplanmasında küme içi (sınıf içi) korelasyon tekniği kullanılmıştır (Şencan, 2005). Testin deneme uygulamasından alınan puanların aritmetik ortalaması 69 (yüz üzerinden) ve standart sapması 13,54 olduğu belirlenmiştir. Testin deneme uygulaması Cronbah Alfa güvenirliği 0,93; Single Measures 0,74; Average Measures 0,93 olarak hesaplanmıştır. Buna dayalı olarak testin güvenilir bir yapıya sahip olduğu söylenebilir (Şencan, 2005).

Asıl uygulamada deney ve kontrol gruplarına BSBT öntest, sontest ve kalıcilık olarak uygulanmıştır. Testin zamana göre tutarlılığını ölçen güvenilirlik katsayısı, test-tekrar test yöntemi ile hesaplanmıştır. Öğrencilerin açık uçlu sorular ve yapılandırılmış gözlem formlarından aldıkları toplam puanlar kullanılarak testin zamana göre tutarlılığı, Pearson korelasyon katsayısı kullanılarak hesaplanmıştır. Analiz sonucunda güvenilirlik katsayısı 0.80 olarak bulunmuştur.

\section{Verilerin Analizi}

Deney grubundaki öğrenciler ile kontrol grubu öğrencileri arasında bilimsel süreç becerilerinin gelişim ve kalıcılık düzeyi açısından anlamlı bir fark olup olmadığını belirlemek için sontest ve kalıcılık testi için ayrı ayrı kovaryans analizi (ANCOVA) yapılmıştır. BSBT'nin sontest ve kalıcılık testleri için elde edilen verilerle ANCOVA yapılabilmesi için tutum ve öğrenme düzeyi puanları kontrol değişkeni olarak alınmış, etkileşimi incelenmiş ve anlamsız olduğu görülmüştür $[F(1,55)=0,31, p>0,05]-[F(1,55)=0,097, p>0,05]$. Bu deney ve kontrol gruplarının istatistiksel kontrol değişkenlerine dayalı olarak öğrenme düzeylerinin yordanmasına ilişkin regresyon doğrularının eğimlerinin eşit olduğunu göstermektedir. Regresyon doğrularının eğimlerinin eşit olması elde edilen verilerle ANCOVA yapılabileceğini göstermektedir.

Bilimsel süreç becerilerine ait alt becerilerin deney ve kontrol grupları arasındaki farklılıkların incelenebilmesi amacıyla, sontest ve kalıcllık testi için çok değişkenli kovaryans analizi (MANCOVA) kullanılmıştır. Analizlerde sontest ve kalıcllık testi için bilimsel süreç becerileri alt becerileri öntest puanı istatistiksel kontrol değişkeni olarak belirlenmiştir.

BSBT'nin alt becerilerinin her birinin sontest ve kalıcılık testi verilerinden çok değişkenli kovaryans analizi (MANCOVA) yapılabilmesi için gerekli olan 


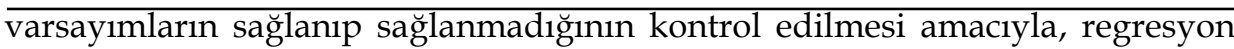
eğrilerinin eşitliği ve varyansların homojenliği test edilmiştir. Bilimsel Süreç Becerilerinin bütün alt becerilerinde regresyon eğrilerinin aynı olmadığı görülmüştür [Wilks' Lambda $F(2,56)=0,00 p<0,05]$. Yine aynı şekilde deney ve kontrol gruplarının bilimsel süreç becerilerinin alt becerilerine ilişkin sontest ve kalıcılık testi puanlarına ait varyansların homojenliğini test etmek amacıyla her biri için Levene Testi kullanılmıştır. Levene testi sontest sonuçlarına göre deney ve kontrol gruplarının ölçülen özellikleri açısından varyanslarının homojen olmadığ1 görülmüştür $[F(1,58)=0.00, p<0.05]$. Levene testi kalıcılık testi sonuçlarında da deney ve kontrol gruplarının ölçülen özellikleri açısından varyanslarının homojen olmadığı görülmüştür $[F(1,58)=0.00, p<0.05]$. Mardia (1971), Glass, vd. (1972), Olson, vd. (1975), Everitt, (1979), araştırmalarında çok değişkenli analizlerde normallik varsayımından sapmanın alfa hatası üzerinde önemli bir etkisi olmadığını belirtmiştir (Akt. Albayrak, Eroğlu, Kalaycı, Kayış, Öztürk, Antalyalı, vd., 2005). Benzer olarak Tabachnick ve Fidell (1996) ile Çokluk, Şekercioğlu ve Büyüköztürk (2010) çok değişkenli analizlerde eş varyanslılık sayıltısının analizler için hayati önem taşıyan analizler olmadığını söylemiştir. İlgili alan yazın desteği yapılan bu çalışmada deney ve kontrol grubundaki öğrenci sayısının düşük olması $(N=60)$ ve Bilimsel Süreç Becerileri alt testlerindeki puan aralığının (ranjın) dar olması nedenleriyle, homojenliğin sağlanmamasına rağmen analizlere devam edilmiştir.

\section{Bulgular}

\section{Bilimsel Süreç Becerilerinin Gelişim ve Kalıcılık Düzeyine İlişkin Bulgular}

Deney ve kontrol gruplarındaki öğrencilerin Bilimsel Süreç Becerileri Testinin sontest ve kalıcılık testi uygulamasından elde ettikleri puanların, karşılaştırılabilmesi için öncelikle tutum ön uygulama puanları, öğrenme düzeyi öntest puanları, bilimsel süreç becerileri öntest puanlarına göre düzeltilmiş ortalama puanları belirlenmiştir. $\mathrm{Bu}$ değerler Tablo $3^{\prime}$ de sunulmuştur. 
Tablo 3.Bilimsel Süreç Becerileri Testi Sontest ve Kahıcılık Testi Uygulaması Puanlarının Ortalama ve Düzeltilmiş Ortalamaları

\begin{tabular}{ccccc}
\hline Testler & Grup & $\mathbf{n}$ & Ortalama & $\begin{array}{c}\text { Düzeltilmiş } \\
\text { Ortalama }\end{array}$ \\
\hline Sontest & Deney & 30 & 77,92 & 78,11 \\
& Kontrol & 30 & 45,69 & 44,92 \\
Kalıcllı & Deney & 30 & 74,17 & 74,45 \\
Testi & Kontrol & 30 & 45,55 & 44,98 \\
\hline
\end{tabular}

Tablo 3'de görüldüğü gibi öğrencilerin Bilimsel Süreç Becerileri Testinden elde ettikleri sontest ve kalıcılık testi düzeltilmiş ortalama puanlarına göre deney grubunun kontrol grubuna göre daha yüksek bir ortalama puana sahip olduğu ifade edilebilir. Grupların düzeltilmiş sontest ve kalıcılık testi ortalama puanları arasındaki farkın anlamlı olup olmadığına ilişkin yapılan ANCOVA sonuçları Tablo 4' ve 5'de sunulmaktadır.

Tablo 4.

Bilimsel Süreç Becerileri Testi Düzeltilmiş Sontest Puanlarınn Gruba Göre ANCOVA Sonuçları

\begin{tabular}{crrrrr}
\hline Varyans Kaynağı & $\begin{array}{c}\text { Kareler } \\
\text { Toplamı }\end{array}$ & sd & $\begin{array}{c}\text { Kareler } \\
\text { Ortalaması }\end{array}$ & F & $\mathrm{p}$ \\
\hline Tutum Ön Uygulama & 173.937 & 1 & 173.937 & 1.175 & .283 \\
Öğrenme Düzeyi Öntest & 2.002 & 1 & 2.002 & .014 & .908 \\
$\begin{array}{c}\text { Bilimsel Süreç Becerileri } \\
\text { Öntest }\end{array}$ & 1151.493 & 1 & 1151.493 & 7.776 & .007 \\
Grup & 16224.747 & 1 & 16224.747 & 109.559 & .000 \\
Hata & 8145.056 & 55 & 148.092 & & \\
Toplam & 254288.526 & 60 & & & \\
\hline
\end{tabular}

Tablo 4 incelendiğinde; deney ve kontrol gruplarının düzeltilmiş sontest puan ortalamaları arasında anlamlı bir fark olduğu $[F(1,55)=109,559, p<0,01]$ görülmektedir. Buna bağlı olarak grupların düzeltilmiş sontest puanları 
arasında yapılan Bonferroni testi sonuçlarına göre deney grubu sontest puan ortalaması $(\bar{X}=78,11)$ ile kontrol grubu $(\bar{X}=44,92)$ arasinda deney grubu lehine anlamlı bir fark bulunmaktadır. Hesaplanan etki büyüklüğü (effect size) ise $\eta^{2}=0,65^{\prime}$ dir. Bu değer $0.14^{\prime}$ den büyük olduğu için etkinin gücü yüksek olarak ifade edilebilir (Cohen, 1992; Cohen, 1998).

Tablo 5.

Bilimsel Süreç Becerileri Testi Düzeltilmiş Kalıcılık Testi Puanlarının Gruba Göre ANCOVA Sonuçları

\begin{tabular}{|c|c|c|c|c|c|}
\hline Varyans Kaynağı & Kareler Toplamı & sd & Kareler Ortalaması & $\mathrm{F}$ & $\mathrm{p}$ \\
\hline Tutum Ön Uygulama & 50.021 & 1 & 50.021 & .456 & .502 \\
\hline Öğrenme Düzeyi Öntest & 0.758 & 1 & 0.758 & .007 & .934 \\
\hline Bilimsel Süreç Becerileri Öntest & 999.811 & 1 & 999.811 & 9.109 & .004 \\
\hline Grup & 12874.804 & 1 & 12874.804 & 117.298 & .000 \\
\hline Hata & 6036.860 & 55 & 109.761 & & \\
\hline Toplam & 234425.278 & 60 & & & \\
\hline
\end{tabular}

Tablo 5 incelendiğinde; deney ve kontrol gruplarının düzeltilmiş kalıcılık puan ortalamaları arasında anlamlı bir farkın olduğu $[F(1,55)=117.298 p<0,01]$ görülmektedir. Buna bağlı olarak grupların düzeltilmiş kalıcılık testi puanları arasında yapılan Bonferroni testi sonuçlarına göre deney grubu kalıcılık puan ortalaması $(\bar{X}=74,45)$ ile kontrol grubu $(\bar{X}=44,98)$ arasinda anlamlı bir fark bulunmaktadır. Hesaplanan etki büyüklüğü (effect size) ise $\eta^{2}=0,66$ dır. Bu değer 0.14 'den büyük olduğu için etkinin gücü büyük olarak ifade edilebilir (Cohen, 1992; Cohen, 1998).

Elde edilen bu sonuçlar dördüncü sınıf fen ve teknoloji dersinde 5E Öğrenme Modeli'nin uygulandığı deney grubu ile mevcut programın uygulandığı kontrol grubu arasında bilimsel süreç becerileri açısından hem sontest hem de kalıcılık testinde deney grubu lehine anlamlı bir fark olduğunu göstermektedir.

\section{Bilimsel Süreç Becerilerinin Alt Becerilerine İlişkin Bulgular}

Araştırmanın ikinci alt problemine bağlı olarak deney ve kontrol gruplarındaki öğrencilerin bilimsel süreç becerilerinin alt becerilerine ait test puanlarının 
birbirinden anlamlı bir farklılık gösterip göstermediğinin belirlenebilmesi amacıyla sontest ve kalıcılık testleri için çok değişkenli kovaryans analizi (MANCOVA) yapılmıştır. Bu analizler, her bir alt beceri için ayrı ayrı verilmiştir. Deney ve kontrol grubunda öğrencilerin bilimsel süreç becerisi alt becerilerinden elde ettikleri puanların karşılaştırılabilmesi için, öncelikle alt becerilere ait ön- test puanlarına göre düzeltilmiş ortalama puanları belirlenmiştir. Bu değerler Tablo 6 'da sunulmuştur.

Tablo 6.

Bilimsel Süreç Becerileri Alt Becerilerine Ait Sontest ve Kalıcılık Testi Puanlarının Ortalama ve Düzeltilmiş Ortalamaları

\begin{tabular}{|c|c|c|c|c|}
\hline Bilimsel Süreç Becerileri Alt Becerileri & Grup & n & Ortalama & $\begin{array}{c}\text { Düzeltilmiş } \\
\text { Ortalama }\end{array}$ \\
\hline \multirow[t]{2}{*}{ Gözlem Sontesti } & Deney & 30 & 97,55 & 96,42 \\
\hline & Kontrol & 30 & 59,08 & 60,22 \\
\hline \multirow[t]{2}{*}{ Gözlem Kalıcılık Testi } & Deney & 30 & 97,22 & 96,06 \\
\hline & Kontrol & 30 & 59,08 & 60,24 \\
\hline \multirow{2}{*}{ Ölçme Sontesti } & Deney & 30 & 93 & 92,51 \\
\hline & Kontrol & 30 & 54,33 & 54,81 \\
\hline \multirow{2}{*}{ Ölçme Kalıcılık Testi } & Deney & 30 & 92,66 & 92,14 \\
\hline & Kontrol & 30 & 54,33 & 54,85 \\
\hline \multirow{2}{*}{ Sinıflandırma Sontesti } & Deney & 30 & 84,79 & 83,42 \\
\hline & Kontrol & 30 & 40 & 41,36 \\
\hline \multirow{2}{*}{ Sınıflandırma Kalıcılık Testi } & Deney & 30 & 84,58 & 83,55 \\
\hline & Kontrol & 30 & 40 & 41,02 \\
\hline \multirow{2}{*}{ Tahmin Etme Sontesti } & Deney & 30 & 51,33 & 51,68 \\
\hline & Kontrol & 30 & 22,83 & 22,48 \\
\hline \multirow{2}{*}{ Tahmin Etme Kalıcılık Testi } & Deney & 30 & 50,83 & 51,16 \\
\hline & Kontrol & 30 & 22,83 & 22,50 \\
\hline \multirow{2}{*}{ Çıkarım Yapma Sontesti } & Deney & 30 & 82,91 & 82,65 \\
\hline & Kontrol & 30 & 46,87 & 47,13 \\
\hline \multirow{2}{*}{ Çıkarım Yapma Kalıcılık Testi } & Deney & 30 & 82,08 & 81,81 \\
\hline & Kontrol & 30 & 46,25 & 46,52 \\
\hline
\end{tabular}


5E Öğrenme Modeli’ne Göre Düzenlenmiş Eğitim Durumlarının Bilimsel Süreç Becerilerine Etkisi

$\begin{array}{lcccc} & & & 63 \\ \text { Bilimsel İletişim Kurma Sontesti } & \text { Deney } & 30 & 85 & 85,53 \\ & \text { Kontrol } & 30 & 58,75 & 58,21 \\ \text { Bilimsel İletişim Kurma Kalıcılık Testi } & \text { Deney } & 30 & 83,33 & 84,06 \\ & \text { Kontrol } & 30 & 58,33 & 57,60 \\ \text { Deney Yapma Sontesti } & \text { Deney } & 30 & 78,95 & 80,09 \\ & \text { Kontrol } & 30 & 63,81 & 62,67 \\ \text { Deney Yapma Kalıcılık Testi } & \text { Deney } & 30 & 75,83 & 76,86\end{array}$

\section{Tablo 6. (Devam)}

Bilimsel Süreç Becerileri Alt Becerilerine Ait Sontest ve Kalıcilık Testi Puanlarının Ortalama Ve Düzeltilmiş Ortalamaları

\begin{tabular}{lcccc}
\hline \multicolumn{1}{c}{ Bilimsel Süreç Becerileri Alt Becerileri } & Grup & n & Ortalama & $\begin{array}{c}\text { Düzeltilmiş } \\
\text { Ortalama }\end{array}$ \\
\hline Hipotez Kurma ve Test Etme Sontesti & Deney & 30 & 73,01 & 72,21 \\
Hipotez Kurma ve Test Etme Kalıcllı Testi & Kontrol & 30 & 35,05 & 34,62 \\
& Deney & 30 & 72,81 & 72,07 \\
Değişkenleri Belirleme ve Kontrol Etme Sontesti & Kontrol & 30 & 34,62 & 35,36 \\
& Deney & 30 & 79,99 & 79,71 \\
Değişkenleri Belirleme ve Kontrol Etme Kalıcllk Testi & Kontrol & 30 & 36,66 & 36,94 \\
Veri Toplama Sontesti & Deney & 30 & 78,88 & 78,64 \\
& Kontrol & 30 & 36,66 & 36,90 \\
Veri Toplama Kalıclık Testi & Deney & 30 & 89,16 & 90,16 \\
& Kontrol & 30 & 50 & 49 \\
Veri Yorumlama Sontesti & Deney & 30 & 88,33 & 89,34 \\
Veri Yorumlama Kalıcılık Testi & Kontrol & 30 & 50 & 48,99 \\
& Deney & 30 & 86,66 & 85,93 \\
& Kontrol & 30 & 48,33 & 49,06 \\
& Deney & 30 & 86,66 & 86,00 \\
& Kontrol & 30 & 47,91 & 48,57
\end{tabular}




\begin{tabular}{lcccc}
\hline Işe Vuruk Tanımlama Sontesti & Deney & 30 & 84,80 & 84,82 \\
& Kontrol & 30 & 31,47 & 31,46 \\
İşe Vuruk Tanımlama Kalıcılık Testi & Deney & 30 & 84,43 & 84,44 \\
Model Oluşturma Sontesti & Kontrol & 30 & 31,10 & 31,10 \\
& Deney & 30 & 85,71 & 86,19 \\
Model Oluşturma Kalıcılık Testi & Kontrol & 30 & 53,80 & 53,32 \\
& Deney & 30 & 84,99 & 85,42 \\
\hline
\end{tabular}

Tablo 6'da görüldüğ̈ü gibi, öğrencilerin bilimsel süreç becerileri alt becerilerine ilişkin sontest ve kalıcılık testi ortalama puanlarına göre, her alt beceride deney grubunun kontrol grubuna göre daha yüksek bir ortalama puana sahip olduğu ifade edilebilir. Her bir alt beceri için, grupların düzeltilmiş sontest ve kalıcılık testi ortalama puanları arasındaki farkın anlamlı olup olmadığına ilişkin yapılan çok değiş̧enli kovaryans analizi (MANCOVA) sonuçları Tablo 7'de sunulmaktadir.

Tablo 7.

Deney ve Kontrol Gruplarının Bilimsel Süreç Becerileri Alt Becerilerine İlişkin Sontest ve Kalıcılık Testi Puanları Çok Değiş̧kenli Kovaryans Analizi Sonuçları

\begin{tabular}{|c|c|c|c|c|c|c|c|}
\hline Kaynak & $\begin{array}{c}\text { Bağımlı } \\
\text { Değişken }\end{array}$ & $\begin{array}{c}\text { Kareler } \\
\text { Ortalaması }\end{array}$ & Sd & $\begin{array}{c}\text { Kareler } \\
\text { Toplamı }\end{array}$ & $\mathbf{F}$ & $\mathrm{p}$ & $\begin{array}{c}\text { Kismi } \\
\text { eta } \\
\text { kare }\end{array}$ \\
\hline \multirow[t]{2}{*}{ Gözlem Öntesti } & Gözlem Sontesti & 19273,82 & 1 & 19273,82 & 33,31 & ,00 & ,36 \\
\hline & $\begin{array}{c}\text { Gözlem Kalıcılık } \\
\text { Testi }\end{array}$ & 18878,72 & 1 & 18878,72 & 32,58 & ,00 & ,36 \\
\hline Ölçme & Ölçme & 21277,36 & 1 & 21277,36 & 41,03 & ,00 & ,41 \\
\hline \multirow[t]{3}{*}{ Öntesti } & Sontesti & & & & & & \\
\hline & Ölçme & 20818,57 & 1 & 20818,57 & 42,34 & ,00 & ,42 \\
\hline & Kalıcılık Testi & & & & & & \\
\hline
\end{tabular}


5E Öğrenme Modeli'ne Göre Düzenlenmiş Eğitim Durumlarının Bilimsel Süreç Becerilerine Etkisi

65

Tablo 7. (Devam)

Deney ve Kontrol Gruplarının Bilimsel Süreç Becerileri Alt Becerilerine İlişkin Sontest ve Kalıcılık Testi Puanları Çok Değişkenli Kovaryans Analizi Sonuçları

\begin{tabular}{|c|c|c|c|c|c|c|c|}
\hline Kaynak & $\begin{array}{c}\text { Bağımlı } \\
\text { Değişken }\end{array}$ & $\begin{array}{c}\text { Kareler } \\
\text { Ortalaması }\end{array}$ & Sd & $\begin{array}{c}\text { Kareler } \\
\text { Toplamı }\end{array}$ & $\mathbf{F}$ & $p$ & $\begin{array}{c}\text { Kismi } \\
\text { eta kare }\end{array}$ \\
\hline \multirow{2}{*}{$\begin{array}{c}\text { Sinıflandırma } \\
\text { Öntesti }\end{array}$} & $\begin{array}{l}\text { Siniflandirma } \\
\text { Sontesti }\end{array}$ & 25871,06 & 1 & 25871,06 & 32,46 &, 00 &, 36 \\
\hline & $\begin{array}{l}\text { Sinıflandirma } \\
\text { Kalıcılık Testi }\end{array}$ & 26450,71 & 1 & 26450,71 & 37,05 &, 00 & ,39 \\
\hline \multirow{2}{*}{$\begin{array}{c}\text { Tahmin Etme } \\
\text { Öntesti }\end{array}$} & $\begin{array}{l}\text { Tahmin Etme } \\
\text { Sontesti }\end{array}$ & 12681,63 & 1 & 12681,63 & 36,66 &, 00 & ,39 \\
\hline & $\begin{array}{l}\text { Tahmin Etme } \\
\text { Kalıcılık Testi }\end{array}$ & 12218,62 & 1 & 12218,62 & 44,15 &, 00 & ,43 \\
\hline \multirow{3}{*}{$\begin{array}{c}\text { Çıkarım Yapma } \\
\text { Öntesti }\end{array}$} & Çıkarım Yapma & 18915,98 & 1 & 18915,98 & 55,31 &, 00 & 49 \\
\hline & Sontesti & & & & & & \\
\hline & $\begin{array}{c}\text { Çıkarım Yapma } \\
\text { Kalıcılık Testi }\end{array}$ & 18671,62 & 1 & 18671,62 & 46,67 &, 00 & ,45 \\
\hline \multirow[t]{2}{*}{$\begin{array}{l}\text { Bilimsel İletişim } \\
\text { Kurma Öntesti }\end{array}$} & $\begin{array}{l}\text { Bilimsel İletişim } \\
\text { Kurma Sontesti }\end{array}$ & 11027,78 & 1 & 11027,78 & 16,76 &, 00 & ,22 \\
\hline & $\begin{array}{c}\text { Bilimsel İletişim } \\
\text { Kurma Kalıcılık } \\
\text { Testi }\end{array}$ & 10345,61 & 1 & 10345,61 & 16,27 &, 00 & ,22 \\
\hline Deney Yapma & Deney Yapma & 4060,47 & 1 & 4060,47 & 47,31 &, 00 & ,45 \\
\hline \multirow[t]{2}{*}{ Öntesti } & Sontesti & & & & & & \\
\hline & $\begin{array}{l}\text { Deney Yapma } \\
\text { Kalıcılık Testi }\end{array}$ & 2731,12 & 1 & 2731,12 & 29,43 &, 00 & ,34 \\
\hline \multirow[t]{2}{*}{$\begin{array}{l}\text { Hipotez Kurma ve Test } \\
\text { Etme Öntesti }\end{array}$} & $\begin{array}{l}\text { Hipotez Kurma } \\
\text { ve Test Etme } \\
\text { Sontesti }\end{array}$ & 19445,39 & 1 & 19445,39 & 59,44 &, 00 &, 51 \\
\hline & $\begin{array}{l}\text { Hipotez Kurma } \\
\text { ve Test Etme } \\
\text { Kalıcılik Testi }\end{array}$ & 19816,33 & 1 & 19816,33 & 69,90 &, 00 &, 55 \\
\hline
\end{tabular}




\begin{tabular}{|c|c|c|c|c|c|c|c|}
\hline 66 & & & ge E & Dergisi 201 & 1: 45-79 & & \\
\hline \multirow[t]{2}{*}{$\begin{array}{c}\text { Değişkenleri Belirleme } \\
\text { ve Kontrol Etme } \\
\text { Öntesti }\end{array}$} & $\begin{array}{c}\text { Değişkenleri } \\
\text { Belirleme ve } \\
\text { Kontrol Etme } \\
\text { Sontesti }\end{array}$ & 27247,93 & 1 & 27247,93 & 55,32 &, 00 & ,049 \\
\hline & $\begin{array}{l}\text { Değişkenleri } \\
\text { Belirleme ve } \\
\text { Kontrol Etme } \\
\text { Kalıcılık Testi }\end{array}$ & 25952,77 & 1 & 25952,77 & 52,82 & ,00 & ,048 \\
\hline \multirow[t]{2}{*}{$\begin{array}{c}\text { Veri Toplama } \\
\text { Öntesti }\end{array}$} & $\begin{array}{l}\text { Veri Toplama } \\
\text { Sontesti }\end{array}$ & 25207,37 & 1 & 25207,37 & 20,20 & ,00 & ,26 \\
\hline & $\begin{array}{l}\text { Veri Toplama } \\
\text { Kalıcılık Testi }\end{array}$ & 24226,36 & 1 & 24226,36 & 19,45 & ,00 & ,25 \\
\hline \multirow[t]{2}{*}{$\begin{array}{c}\text { Veri Yorumlama } \\
\text { Öntesti }\end{array}$} & $\begin{array}{c}\text { Veri Yorumlama } \\
\text { Sontesti }\end{array}$ & 20215,68 & 1 & 20215,68 & 38,68 & ,00 & ,40 \\
\hline & $\begin{array}{c}\text { Veri Yorumlama } \\
\text { Kalıcilık Testi }\end{array}$ & 20841,86 & 1 & 20841,86 & 38,39 & ,00 & 40 \\
\hline
\end{tabular}

\section{Tablo 7. (Devam)}

Deney ve Kontrol Gruplarmın Bilimsel Süreç Becerileri Alt Becerilerine İlişkin Sontest ve Kalıcılık Testi Puanları Çok Değişkenli Kovaryans Analizi Sonuçları

\begin{tabular}{|c|c|c|c|c|c|c|c|}
\hline Kaynak & $\begin{array}{c}\text { Bağımlı } \\
\text { Değişken }\end{array}$ & $\begin{array}{l}\text { Kareler } \\
\text { Ortalaması }\end{array}$ & Sd & $\begin{array}{c}\text { Kareler } \\
\text { Toplamı }\end{array}$ & F & $p$ & $\begin{array}{l}\text { Kismi } \\
\text { eta } \\
\text { kare }\end{array}$ \\
\hline \multirow[t]{2}{*}{$\begin{array}{c}\text { İşe Vuruk } \\
\text { Tanımlama Öntesti }\end{array}$} & $\begin{array}{l}\text { İşe Vuruk } \\
\text { Tanımlama } \\
\text { Sontesti }\end{array}$ & 42693,81 & 1 & 42693,81 & 80,54 & ,00 &, 58 \\
\hline & $\begin{array}{c}\text { İşe Vuruk } \\
\text { Tanımlama } \\
\text { Kalıcılık Testi }\end{array}$ & 42662,84 & 1 & 42662,84 & 78,79 & ,00 &, 52 \\
\hline \multirow[t]{2}{*}{$\begin{array}{c}\text { Model Oluşturma } \\
\text { Öntesti }\end{array}$} & $\begin{array}{c}\text { Model } \\
\text { Oluşturma } \\
\text { Sontesti }\end{array}$ & 16161,14 & 1 & 16161,14 & 24,84 & ,00 & ,30 \\
\hline & $\begin{array}{c}\text { Model } \\
\text { Oluşturma } \\
\text { Kalıcılık Testi }\end{array}$ & 15822,41 & 1 & 15822,41 & 26,90 & ,00 & ,32 \\
\hline
\end{tabular}


Tablo 7 incelendiğinde; gözlem, ölçme, sınıflandırma, tahmin etme, çıkarım yapma, bilimsel iletişim kurma, deney yapma, hipotez kurma ve test etme, değişkenleri belirleme ve kontrol etme, verileri toplama, verileri yorumlama, işlevsel tanımlama ve model oluşturma alt becerilerine ilişkin deney ve kontrol gruplarının düzeltilmiş sontest ve kalıcılık testi puan ortalamaları arasında anlamlı bir farkın olduğu (gözlem sontest $[F(1,55)=33,31, p<0,05]$, gözlem kalıc1lık testi $[F(1,55)=32,58, p<0,05]$ ), (ölçme sontest $[F(1,55)=41,03, p<0,05]$, ölçme kalıcılık testi $[F(1,55)=42,34, p<0,05])$, (sınıflandırma sontest $[F(1,55)=$ $32,46, p<0,05]$, siniflandirma kalıcilık testi $[F(1,55)=37,05, p<0,05])$, (tahmin etme sontest $[F(1,55)=36,66, p<0,05]$, tahmin etme kalıcllik testi $[F(1,55)=44,15, p<0,05])$, (çıkarım yapma sontest $[F(1,55)=55,31, p<0,05]$, çıkarım yapma kalıcılık testi $[F(1,55)=46,67, p<0,05])$, (bilimsel iletişim kurma sontest $[F(1,55)=16,76, p<0,05]$, bilimsel iletişim kurma kalıcılık testi $[F(1,55)=16,27, p<0,05])$, (deney yapma sontest $[F(1,55)=47,31, p<0,05]$, deney yapma kalıcilik testi $[F(1,55)=29,43$, $p<0,05]$ ), (hipotez kurma ve test etme sontest $[F(1,55)=59,44, p<0,05]$, hipotez kurma ve test etme kalıcılık testi $[F(1,55)=69,90, p<0,05]$ ), (değişkenleri belirleme ve kontrol etme sontest $([F(1,55)=55,32, p<0,05]$, değişkenleri belirleme ve kontrol etme kalıcılık testi $[F(1,55)=52,82, p<0,05]$ ), (verileri toplama sontest $[F(1,55)=20,20, p<0,05]$, verileri toplama kalıcılik testi $[F(1,55)=19,45, p<0,05])$, (verileri yorumlama sontest $[F(1,55)=38,68, p<0,05]$, verileri yorumlama kalıcilik testi $[F(1,55)=38,39, p<0,05])$, (işlevsel tanimlama sontest $[F(1,55)=80,54, p<0,05]$ işlevsel tanımlama kalıcılık testi $[F(1,55)=78,79, p<0,05]$ ), (model oluşturma sontest $[F(1,55)=24,84, p<0,05]$, model oluşturma kalıcılık testi $[F(1,55)=26,90$, $p<0,05])$ görülmektedir. $\mathrm{Bu}$ sonuçlar, deney grubunun bilimsel süreç becerilerinin bütün alt becerilerinde düzeltilmiş sontest ve kalıcılık puan ortalamalarının, kontrol grubunun düzeltilmiş sontest ve kalıcılık puan ortalamalarından anlamlı şekilde büyük olduğunu göstermektedir.

Tablo 7 incelendiğinde; bilimsel süreç becerilerinin alt becerileri için hesaplanan etki büyüklüğü (kımi eta kare) ise gözlem sontestinde $\eta^{2}=0,36$, gözlem kalıcılık testinde $\eta^{2}=0,36$; ölçme sontestinde $\eta^{2}=0,41$, gözlem kalıcılık testinde $\eta^{2}=0.42$; sinuflandirma sontestinde $\eta^{2}=0,36$, sinıflandirma kalıcılık testinde $\eta^{2}=0.39$; tahmin etme sontestinde $\eta^{2}=0,39$, tahmin etme kalıcılık testinde $\eta^{2}=0.43$; çıkarım yapma sontestinde $\eta^{2}=0,49$, çıkarım yapma kalıcılık testinde $\eta^{2}=0.45$; bilimsel iletişim kurma sontestinde $\eta^{2}=0,22$ bilimsel iletişim kurma kalıcılık testinde $\eta^{2}=$ 0,22 ; deney yapma sontestinde $\eta^{2}=0,45$, deney yapma kalıcılık testinde $\eta^{2}=0,34$; hipotez kurma ve test etme sontestinde $\eta^{2}=0,51$, hipotez kurma ve test etme kalıcılık testinde $\eta^{2}=0,55$; değişkenleri belirleme ve kontrol etme sontestinde $\eta^{2}=0,49$, değişkenleri belirleme ve kontrol etme kalıcılık testinde $\eta^{2}=0,48$; verileri toplama sontestinde $\eta^{2}=0,26$, verileri toplama kalıcilik testinde $\eta^{2}=0,25$; verileri yorumlama sontestinde $\eta^{2}=0,40$, verileri yorumlama kalıc1lik testinde 
$\eta^{2}=0,40$; işlevsel tanımlama sontestinde $\eta^{2}=0,58$, işlevsel tanımlama kalıcılık testinde $\eta^{2}=0,52$ ve model oluşturma sontestinde $\eta^{2}=0,30$, model oluşturma kalıc1lik testinde $\eta^{2}=0,32^{\prime}$ dir. Bu değerlerin hepsi $0.14^{\prime}$ den büyük olduğu için etkinin gücü yüksek olarak ifade edilebilir (Cohen, 1992; Cohen, 1998).

\section{Tartışma}

$\mathrm{Bu}$ araştırma, son yıllarda üzerinde çokça durulmaya başlanan yapılandırmacı anlayışın uygulamadaki örneği olan $5 \mathrm{E}$ Öğrenme Modeli ve bilimsel süreç becerilerinin performansa dayalı ölçülmesi üzerine hazırlanmışır. Ayrıca çalışmada, bilimsel süreç becerilerinin performansa dayalı ölçümüyle birlikte, her bir alt becerinin gelişimi ve kalıcılığının karşılaştırılması da yapılmıştır. Bu karşılaştırma sayesinde öğretmenlere ve uzmanlara bilimsel süreç becerilerinin ölçümünde her bir alt becerinin bütünle ilişkili olarak nasıl ölçülebileceğine ilişkin ipuçları da verilmiştir.

Araştırmada, deney grubunda 5E Öğrenme Modeli'ne uygun bir program uygulanırken, kontrol grubunda mevcut programdan hareketle hazırlanan MEB'in ders ve çalışma kitabındaki etkinliklerinin sırasıyla işlendiği, süreçte öğretmenin yönlendirici olmasından çok bilgiyi aktaran olduğu öğretmeöğrenme süreci yürütülmüştür. 5E Öğrenme Modeli'ne göre düzenlenmiş öğretimin bilimsel süreç becerilerinin gelişimi üzerindeki etkisinin incelenebilmesi amacıyla, Bilimsel Süreç Becerileri Testi deney ve kontrol grubu öğrencilerine denel işlem öncesinde, denel işlem sonunda ve denel işlemden yaklaşık üç ay sonra olmak üzere üç defa uygulanmıştır. Deney ve kontrol grupları testlerden elde ettikleri puanlar bakımından karşılaştırılmıştır. Bulgular, dördüncü sınıf fen ve teknoloji dersinde 5E Öğrenme Modeli'nin uygulandığı deney grubu ile mevcut programın uygulandığı kontrol grubu arasında bilimsel süreç becerilerinin gelişimi açısından hem sontestte hem de kalıcılık testinde deney grubu lehine anlamlı bir fark olduğunu göstermektedir.

Alanyazın incelendiğinde bu araştırmadaki sonuçları destekleyen araştırmalara (Buntod, Suksringam ve Singseevo, 2010; Özaydın, 2010; Anagün, 2009; Öztürk, 2008; Önal, 2008; Sevinç, 2008; Özsevgeç, 2007; Turpin ve Cage, 2004) rastlanmaktadır. Buntod, Suksringam, ve Singseevo (2010), çalışmalarında bilişsel tekniklerle desteklenen 5E Öğrenme Modeli'nin bilimsel süreç becerilerini geliştirdiğini ortaya koymuştur. Özaydın (2010), çalışmasında ilköğretim yedinci sınıf fen ve teknoloji dersi "Vücudumuzda Sistemler" ünitesi için 5E Öğrenme Modeli'ne göre hazırlanan etkinliklerin öğrencilerin bilimsel süreç becerilerinde anlamlı bir farklılık meydana getirdiğini tespit etmiştir. Turpin ve Cage (2004), çalışmasında yapılandırmacı etkinliklere dayalı fen programının öğrencilerin bilimsel süreç becerilerine etkisini incelediği 
araştırmasında, bilimsel süreç beceri testi sontest puanları arasında anlamlı bir farklılı̆̆ın olduğunu ortaya koymuştur.

2005 yılında geliştirilen Fen ve Teknoloji Dersi Öğretim Programı'nın temel amaçlarından biri öğrencilerin bilimsel süreç becerilerini geliştirmek diğeri de fen okuryazarı yetiştirmektir. Öğrencilere bu becerileri kazandıracak olan fen öğretmenlerinin sınıf içinde yapılandırmacı yaklaşıma dayalı öğretim stratejilerini ve yöntemlerini ne derece uyguladıkları da tartışılır. Türkiye'deki resmi program yapılandırmacılığı ne kadar benimsese de, öğretmenlerin eski alışkanlıklarından vazgeçmediği görülmektedir (Özaydın, 2010). Bu anlamda bakıldığında, hazırlanan programların yapılandırmacı anlayışa uygun olmasından çok, öğretmenlerin yapılandırmacı anlayışa hazır olması daha önemli görülmektedir.

Araştırmada, denel işlem bölümünde de anlatıldı̆̆ı gibi, deney grubunun öğretmeni denel işlemi uygulamadan önce, yapılandırmacı anlayış ve 5E modeliyle ilgili bilgiye sahip olmuştur. Kontrol grubundaki öğretmen ise böyle bir bilgiye sahip olmamıştır. Deney grubundaki öğretmen yapılandırmacı anlayışa uygun ders materyallerini sınıfta uygularken, kontrol grubundaki öğretmen ağırlıklı olarak süreci ders kitabından yürütmüştür. Deney grubunda uygulanan materyal zenginliğinden daha çok denel işlemden önce ve deneli işlem süresince deney grubundaki çalışmayı yürüten öğretmenin bakış açısındaki değişimin sağlanması, onun öğrenme sürecinde daha özenli davranmasına neden olmuştur. Denel işlemi yürüten öğretmen, bilgi aktarandan daha çok yönlendirici olmuş, bütüncül bir değerlendirme anlayışını benimsemiş, öğrencilerle birlikte öğrenmiş ve araştırma yapmıştır. Öğretmenin yaptıkları, 5E öğrenme modelinin uygulandı̆̆ı deney grubunun bilimsel süreç becerileri sontest ve kalıcılık puanlarının kontrol grubu puanlarından anlamlı şekilde farklı olmasını sağlamıştır.

Akar ve Yıldırım'ın (2004) eylem araştırması şeklinde yürüttükleri çalışmanın bulguları incelendiğinde, yapılandırmacı öğretmen adaylarının aktif öğrenme ortamlarında daha yüksek motivasyon ile öğrendikleri görülmüştür. Ayrıca araştırmada; yapılandırmacı ortam sayesinde, bireylerin kendilerini gerçek ve anlamlı öğrenmeyi yansıtan ortamlarda gördükleri; bireylerin sınıf yönetimi konusundaki becerileri öğrenirken, kendilerini öğretmen olarak gördükleri ve öğrendiklerini yaşama geçirebilmek için okullardaki farklılıkları ve dinamikleri sürekli sorguladıkları sonuçlarına da ulaşılmıştır. Plourde ve Alawiye (2003) araştırmalarında öğretmen adaylarının yapılandırmacı yaklaşımla ilgili bilgileri arttıkça, sınıfta yapılandırmacı yaklaşımın ilkelerine daha çok başvurdukları bulgusuna ulaşmışlardır. 
Denel işlemin yürütüldüğgu süreçte deney grubundaki öğrencilerin işbirliğine dayalı grup çalışmaları sonucu işe yarar bir ürün ortaya çıarmaları, onların hem duyuşsal özelliklerini hem de akademik bilgi ve becerilerini olumlu yönde etkilediği gözlenmiştir. İlköğretim düzeyindeki fen ve teknoloji derslerinde grup çalışmalarına yer verilmesi öğrencilerin akademik bilgi, beceri ve tutumlarına önemli katkılar sağlayabilir. Süreçte işbirliği yapılarak sürdürülen çalışmalarda öğrencilerin, eğlenerek doyum almalarını sağlayıp onların güdülenme düzeylerini de arttırabilir. Ayrıca deney grubundaki öğrencilerin insiyatif alması, yorumlarını gözden geçirmesi, çok yönlü düşünmesi, kendi sonuçlarını ortaya koyabilmesi sağlanmıştır.

Araştırmada yapılandırmacı anlayışın bir parçası olarak ele alınan işbirlikli öğrenme yönteminin öğrenci başarısını artırdığı sonucu, işbirlikli öğrenmenin çeşitli tekniklerinin uygulandığı ve işbirlikli öğrenmenin öğrenci başarısı üzerindeki olumlu etkilerini ortaya çıkaran bir çok araştırma (Kurt, 2000; Nakipoğlu, 2001; Oral, 2000, akt. Selcan, 2008); Becker ve Mousiniyet, 2004; Bilgin ve Geban, 2004; Çelebi, 2006; Özkan, 2001; Selcan, 2008) tarafından da desteklenmektedir. Özkan (2001), çalışmasında yapılandırmacı öğrenme ortamlarında öğrencilerin sıkça küçük ya da büyük grup etkinliklerine katıldığını ve beraber çalışıp işbirliği yapıp düşünme yeteneklerini ve birlikte çalışırken başkalarını kabullenme duygularını geliştirdiğini saptamıştır. Becker ve Mousiniyet (2004) geleneksel yöntemlerle yapılandırmacı yaklaşıma dayalı açık uçlu diyalog, problem temelli ve işbirlikli öğrenmenin öğrencilerin başarı ve tutumlarına etkisini incelemiş̧ir. Geleneksel öğretimin uygulandığı gruplara göre yapılandırmacı yaklaşımla ders işleyen grup, sontest sonuçlarına göre daha yüksek başarı elde etmiş ve araştırmanın sonunda yapılandırmacı yaklaşımı tercih etmişlerdir. Çelebi (2006), yaptığı araştırmada, yapılandırmacı yaklaşımına dayalı işbirlikli öğrenmenin uygulandığı deney grubundaki öğrencilerin, geleneksel öğretimin uygulandığı kontrol grubundaki öğrencilere göre daha yüksek erişi elde ettiklerini; deney grubundaki öğrencilerin bu yöntemle dersi daha iyi öğrendiklerini ve bu yöntemle ders işlemekten memnun olduklarını; deney grubundaki öğrencilerin, grup süreçlerinde paylaşma, arkadaşlık, yardımlaşma, sorumluluk alma, bilimsel yöntem kullanma ve inceleme araştırma yapma gibi birçok becerilerini geliştirdiklerini ortaya koymuştur. Selcan (2008), araştırmasında yapılandırmacı yaklaşıma dayalı işbirlikli öğrenme yönteminin, öğrencilerin akademik başarılarını ve çevreye yönelik tutum ve davranışlarını olumlu yönde etkilediği sonucuna varmiştır.

Madill ve ark. (2001) araştırma dayalı öğrenme yaklaşımının öğrenci merkezli öğrenmeyi artırdığı, öğrencilerde bağımsız problem çözmeyi geliştirdiği, öğrenme ortamında öğrenci-öğretmen etkileşimini artırdığını yaptıkları 
araştırma sonucunda ortaya koymuşlardır. Tatar (2006), çalışmasında araştırmaya dayalı öğrenme; öğrencilere bilimsel süreç becerilerini kullanmaları için imkan sağlamakta ve onların bilimsel yöntemler kullanarak bilim insanları gibi çalışmalarına izin verdiğini söylemektedir. Ayrıca araştırmada öğrencilerin kendi başlarına veya grupla yaptıkları çalışmalarda sorumluluk almalarını, kendilerini ifade etmelerini ve öz güvenlerini geliştirdiğini de sağladığı da belirtilmektedir. Bağcı Kılıç (2001), yaptığı araştırmada yapılandırmacı yaklaşımın kişinin kendi bilgilerini kendisinin oluşturduğunu savunan bir eğitim felsefesi olduğunu, bu yaklaşıma dayana fen öğretiminde; bilimsel bilgilerin, kavramların öğrencilere doğrudan aktarılmayıp bilim insanları gibi kendilerinin gözlemleyip, keşfederek, araştırarak, hipotezler kurup, deneyler yaparak problemlerin çözümüne ulaşacaklarını belirtmiştir. Koç (2002), yapılandırmacı öğrenme ortamının duyuşsal ve bilişsel öğrenme ürünleri üzerindeki etkisini araştırdığı çalışmasında, yapılandırmacı öğrenme ortamlarında öğrencilerin dersten daha fazla zevk aldığı, öğrenme etkinliklerine daha istekle katıldığı, kendilerine daha fazla güvendiği, daha fazla iş birliği yaptığı, diğer arkadaşlarının görüşlerini dinlediği ve saygı duyduğu görülmüştür.

Son yıllarda dünyada ve ülkemizde çok bilgiyle donanmış olmanın değil, bilgiye ulaşma yolları ve bu yolları etkili biçimde kullanmak göze çarpan önemli bir değişimdir. Günümüzde bireylerin; günlük yaşamlarında veya mesleki yaşamlarında etkili biçimde kullanmadıkları bilgileri sürekli taşıma zorunluluğu yerine, karşılaştıkları problemleri çözmede kullanacakları bilgilere ulaşmanın yollarını bilen ve etkili biçimde kullanabilen, duruma uygun bilgiyi ayıklayıp yorumlayabilen, araştırmacı kimliğe sahip, durağanlık yerine farklı görüş ve durumlara açık olmaları gerekli hale gelmektedir. Bu özelliklerin kazanılması için günümüz toplumlarında nitelikli insan gücüne giderek daha fazla ihtiyaç duyulmaktadır. Bu durum karşımıza, bilimsel düşünmeyi alışkanlık haline getirmiş bireyleri yetiştirmeye odaklanan bir öğretim sürecinin zorunluluğunu getirmektedir. Bu öğretim sürecindeki bireylerin ise, kendi öğrenmelerinden sorumlu olmaları, yaşayarak, tartışarak, araştırarak, eleştirerek öğrenmeleri gerekmektedir.

\section{Sonuç ve Öneriler}

Sonuç olarak, bu araştırmadan elde edilen bulgular, dördüncü sınıf fen ve teknoloji dersinde 5E Öğrenme Modeli'ne göre düzenlenmiş öğretimin bilimsel süreç becerilerinin hem bütünsel hem de alt becerilerin her birinin gelişimi ve kalıcılığ1 üzerinde mevcut uygulanan programın eğitim durumlarından daha etkili olduğunu göstermektedir. Bu anlamda, fen ve teknoloji derslerinde, 5E 
Öğrenme Modeli bilimsel süreç becerilerini geliştirme yönünde etkili olarak kullanılabilir.

Bilimsel süreç becerilerinin doğası gereği ölçülürken performansa dayalı olması gerektiği düşünülmektedir. Çünkü bir gözlem ya da deney becerisinin gelişip gelişmediğini görebilmek için, o becerinin ölçümü somut olarak uygun araç gereçlerle yapılmalıdır. Bu çalışmada bilimsel süreç becerilerinin ölçümü, öğrencilerin uygun araç gereçlerle deneyi kendi başına yaptığı; yapılan deneyden hareketle bilimsel süreç becerilerine yönelik bütün alt becerilere ilişkin soruları yanıtladığı ya da sınama durumlarını uyguladığı; öğretmenin ise deney sürecini gözlemlediği ve gözlem puanı verdiği performansa dayalı bir ölçme aracıyla yapılmıştır.

Yukarıda ele alınan sonuçlardan yola çıkarak yöneticilere, öğretmenlere ve uzmanlara şunlar önerilebilir;

- Araştırmadan elde edilen sonuçlara göre, 5E Öğrenme Modeli'nin fen ve teknoloji derslerinde bilimsel süreç becerilerinin geliştirilmesi amacıyla kullanilabilir

- 5E Öğrenme Modeli'nin öğretimi planlama ve uygulamaya dönük katkıları dikkate alındığında, program geliştirme çalışmalarında program geliştirme uzmanlarının, öğretmenlerin ya da öğretim elemanlarının öğretimi tasarlama çalışmalarında yapılandırmacı anlayışa odaklanmaları, denemeleri ve değerlendirmeleri için teşvik edilmelerinin gerekli olduğu düşünülmektedir. Bu noktada hizmet içi eğitimler yoluyla öğretmenlere yapılandırmacı anlayışla ilgili alıştırmalar yapma olanağı sunulmalıdır.

- 5E Öğrenme Modeli'nin öğrenme üzerinde etkililiği ve kalıcılığına olumlu katkısıla birlikte öğrencilerde ilgi ve istek uyandıran yönü dikkate alındığında, özellikle öğretmen yetiştiren kurumlarda öğrencilerin bu anlayış çerçevesinde yetiştirilmesinin, meslek alanları açısından önemli katkılar sağlayacağı düşünülmektedir.

- $\mathrm{Bu}$ araştırmada bilimsel süreç becerilerinin gelişimi performansa dayalı ölçme aracından elde edilen verilerden yararlanılarak test edilmiştir. Bilimsel süreç becerilerinin ölçümünde bu araştırmada kullanılan ölçme aracından yararlanilabilir.

- 5E Öğrenme Modeli' nin uygulandığı bir süreçte, öğrencilerin bilimsel süreç becerilerinin derinlemesine incelemesine dönük nitel araştırmalar yapilabilir.

- 5E Öğrenme Modeli'nin etkisi farklı düzey, ders ve eğitim durumlarında denenerek geçerliğinin, işlerliğinin ve kullanışlılığının irdelenmesine dönük çalışmalar yapılabilir. 


\section{Kaynakça}

Abruscato, J. (2000). Teaching children science a discovery approach. Fifty Edition. Boston: Ally and Bacon.

Akar, E. (2005). Asit ve baz kavramlarının anlaşılmasında 5e öğretim modelinin etkisi. (Yayımlanmamış yüksek lisans tezi). Orta Doğu Teknik Üniversitesi, Fen Bilimleri Bölümü, Ankara.

Akar, H. ve Yıldırım, A. (2004). Oluşturmacı öğretim etkinliklerinin sınıf yönetimi dersinde kullanılması: bir eylem araştırması. Sabancı Üniversitesi, İyi Örnekler Konferansı.

Albayrak, A.S., Eroğlu, A., Kalaycı, Ş., Kayış, A., Öztürk, E., Antalyalı, Ö. L., vd. (2005). SPSS uygulamalı çok değişkenli istatistik teknikleri. Ankara: Asil Yayın Dağıtım.

Anagün, Ş.S. (2009). İlköğretim beşinci sinıf öğrencilerinde yapılandırmacı öğrenmeyoluyla fen okuryazarliğı geliştirilmesi: bir eylem araştırması. (Yayımlanmamış doktora tezi). Anadolu Üniversitesi, Eğitim Bilimleri Enstitüsü, İlköğretim Anabilim Dalı, Eskişehir.

Anagün, Ş. S. ve Yaşar, Ş. (2009). İlköğretim beşinci sınıf fen ve teknoloji dersinde bilimsel süreç becerilerinin geliştirilmesi. İlköğretim Online, 8 (3), 843-865.

Andaç, K. (2007). Gözden geçirme stratejisi ile desteklenmiş yapılandırmacı öğrenme yaklaşımının 5e modelinin öğrencilerin basınç konusundaki erişilerine, bilgilerinin kalıclığına ve tutumlarına etkisi. (Yayımlanmamış yüksek lisans tezi). Dicle Üniversitesi, Fen Bilimleri Enstitüsü, Fizik Anabilim Dalı, Diyarbakır.

Aydoğmuş, E. (2008). Lise 2 fizik dersi iş-enerji konusunun öğretiminde 5e modelinin öğrenci başarısına etkisi. (Yayımlanmamış yüksek lisans tezi). Selçuk Üniversitesi, Fen Bilimleri Enstitüsü, Fizik Eğitimi Anabilim Dalı, Konya.

Bağc1 Kılıç, G. (2001). Oluşturmacı fen öğretimi. Kuram ve Uygulamada Eğitim Bilimleri. 1,1.

Bağc1 Kılıç, G. (2003). Üçüncü uluslararası matematik ve fen araştırması (TIMSS): fen öğretimi, bilimsel araştırma ve bilimin doğası. İlköğretim Online, 2(1), 42-51.

Becker, H. K., Mousiniyet, S. (2004). A Comprosion of student's achievement and attitudes between constructivist on traditional clasroom environment 
in thlaind vocational electronic programs. Journal Of Vocational Education Research, 29:133-153

Bell, R. L. (2008). Teaching the nature of science through process skills, activities for grades 3-8. Newyork: Pearson.

Bilgin, İ. ve Geban, Ö. (2004). İşbirlikli öğrenme yöntemi ve cinsiyetin sınıf öğretmenliği bölümü öğretmen adaylarının fen bilgisi dersine karşı tutumlarına, fen bilgisi dersindeki başarılarına etkisinin incelenmesi. Hacettepe Üniversitesi Eğitim Fakültesi Dergisi, 26, 9-18.

Brandt, E.S. (2012). Utilizing an early childhood science curriculum: factors influencing implementation and how variations affect students' skills and attıtudes. (Unpublished doctor's thesis). Doctor of Philosophy Educational Leadership and Innovation Thesis, Faculty of the Graduate School of the University of Colorado.

Buntod, P.C., Suksringam, P. ve Singseevo, A. (2010). Effects of learning environmental education on science process skills and critical thinking of mathayomsuksa 3 students with different learning achievements. Journal of Social Sciences 6 (1), 60-63.

Bybee, R.W. (1997). Achieving scientific literacy: from purposes to practices. Portsmouth: UK, Heinemann.

Bybee, R.W., Taylor, A.J., Gardner, A., Van Scotteer P., Powell, J.C., Westbrook, A., ve Landes, N. (2006). The BSCS 5E instructional model: Origins, effectiveness, and applications. Colorado: Springs.

Campbell, M. (2006). The Effects of the 5e learning cycle model on students' understanding of force and motion concepts. (Unpublished master's thesis). University of Central Florida Department of Teaching and Learning Principles, Florida.

Canlı, Ö. (2009). İlköğretim 8. sinıf fen bilgisi dersi canllarda üreme ve gelişme ünitesinde yapılandırmacı yaklaşıma dayalı 5e modeline uygun etkinliklerin ögrrenci başarı ve tutumlarına etkisi. (Yayımlanmamış yüksek lisans tezi). Selçuk Üniversitesi, Fen Bilimleri Enstitüsü, İlköğretim Anabilim Dalı Fen Bilgisi Eğitimi Programı, Konya.

Carin, A.A. (1993). Teaching science through discovery. Toronto: Macmillan Publishing Company.

Chen, J.H. (2008). Research of elementary school student's learning achievements with the implementation of 5e learning cycle based on nanotechnology curriculum. 
Master's Thesis, Graduate Institite of Mathematics and Science Education, National Pingtung University of Education, Taiwan.

Cohen, J. (1988). Statistical power analysis for the behavioral sciences . NewJersey: Lawrenced Erlbaum Associates, Inc. Publishers. pp 283-286.

Cohen, J. (1992). A power primer. Psychological Bulletin, 112(1), 155-159.

Çelebi, C. (2006). Yapılandırmacılık yaklaşımına dayalı işbirlikli öğretimim 5. sınıf sosyal bilgiler dersinde öğrencilerin erişi ve tutumlarına etkisi. (Yayımlanmamış yüksek lisans tezi). Selçuk Üniversitesi, Konya.

Çokluk, Ö., Şekercioğlu, G. ve Büyüköztürk, Ş. (2010). Sosyal bilimler için çok değişkenli istatistik SPSS ve LISREL uygulamaları. Ankara: Pegem Akademi.

Deren, Ş. (2008). İlköğretim 8. sinıf genetik ünitesinin 5e modeline göre tasarlanan multimedya destekli öğretimin öğrencilerin erişi ve tutumlarına etkisi. (Yayımlanmamış yüksek lisans tezi). Muğla Üniversitesi, Sosyal Bilimler Enstitüsü, Muğla.

Erbağ, S., Şimşek, N. ve Çınar, Y. (2005). Fen bilgisi laboratuar ve uygulamaları. Ankara: Nobel Yayıncılik.

Erdoğdu, S. (2011). Elektrik konularının 5e modeline göre öğretiminin öğrencilerin akademik başarılarına ve tutumlarına etkisi. (Yayımlanmamış yüksek lisans tezi). Selçuk Üniversitesi, Eğitim Bilimleri Enstitüsü, Orta Öğretim Ve Matematik Alanları Eğitimi, Fizik Eğitimi Bilim Dalı, Konya.

Ergin, G. (2006). Fizik eğitiminde 5e modelinin öğrencilerin akademik başarısına, tutumuna

ve hatırlama düzeyine etkisine bir örnek: iki boyutta atış hareketi.

(Yayımlanmamış

doktora tezi). Gazi Üniversitesi, Fen Bilimleri Enstitüsü, Ankara.

Ewers, T.G. (2001). Teacher - directed versus learning cycles methods: Effects on science process skills mastery and teacher efficacy among elemantary education students. (Yayımlanmamış doktora tezi). University of Idaho.

Gabel, D.L. (1993). Handbook of research on science teaching and learning a project of the national science teachers association. New York: Macmillan and Shuster and Prentice Hall International.

Garcia, C. M. (2005). Comparing the 5 e and traditional approach to teaching evolution in a hispanic middle school science classroom. Master Thesis. California State University, California. 
Gatlin, L.S. (1998). The effect of pedagogy informed by constructivism: A comparasion of student achievement across constructivist and tradational classroom environments (Science Education). (Yayımlanmamış doktora tezi). University of New Orleans.

Gürses, E. (2006). Durgun elektrik konusunda yapılandırmacı öğrenme kuramına dayal, 5e modeline uygun olarak geliştirilen dokümanların uygulanması ve etkililiğinin incelenmesi. (Yayımlanmamış yüksek lisans tezi). Karadeniz Teknik Üniversitesi, Fen Bilimleri Enstitüsü, Trabzon.

Harlen, W. (2007). Teaching, learning and assessing science. 5- 12. (4. Edition.) Los Angeles: Sage Publacitions.

Koç, G., (2002). Yapılandırıcı öğrenme yaklaşımının duyuşsal ve bilişsel öğrenme ürünlerine etkisi. (Yayımlanmamış doktora tezi). Hacettepe Üniversitesi, Sosyal Bilimler Enstitüsü, Ankara.

Lancour, K.L. (2005). Process skills for life science. Erişim: 29 Haziran 2010. www.tufts.edu/as/wright_center/products/sci_olympiad/upload_1_15 _05/pdf/process_skills_life_sci_super_and_coach_guide_05.pdf adresinden elde edildi.

Madill, H.M., Amort-Larson, G., Wilson, S.A., Brintnell, S.G., Taylor, E., ve Esmail, S. (2001). Inquiry-based learning: an instructional alternative for occupational therapy education. Occupational Therapy International, 8(3), 198-209.

Martin, D.J. (2006). Elementary science methods. a constructivist approach. thomson higher education 10. Belmont: Davis Drive.

McCormick, B. (2000). Attitude, Achievement, and Classroom Environment in a Learner-Centered Introductory Biology Course. (Unpublished doctor's thesis)., The University of Texas.

Miles, E. (2010). In-service elementary teachers' famulianty, interest, conceptual knowledge, and performance on science process skulls. (Unpublished master's thesis). A Thesis Submitted in Partial Fulfillment of the Requirements for the Master of Science in Education, Southern Illinois University, Department of Curriculum and Instruction in the Graduate School, Carbondale.

Milli Eğitim Bakanlığ1 (MEB). (2005). İlköğretim 4. ve 5. sinıflar fen ve teknoloji dersi öğretim programı. Ankara: Milli Eğitim Basımevi.

Ostlund, K.L. (1992). Science process skalls: assessing hands on student performance. California: Addison Wesley. 
Onal, I. (2008). Özel öğretim yöntemleri 2 dersinde oluşturmacı öğretimin başarı, tutum, bilimsel süreç becerileri ve kalıcılı̆̆a etkisi. (Yayımlanmamış doktora tezi). Orta Doğu Teknik Üniversitesi, Eğitim Bilimleri Bölümü, Ankara.

Önder, E. (2011). Fen ve teknoloji dersi "canlilarda üreme, büyüme ve gelişme" ünitesinde kullanılan yapılandırmacı 5e öğrenme modelinin 6. sınıf öğrencilerinin başarılarına etkisi. (Yayımlanmamış yüksek lisans tezi). Selçuk Üniversitesi, Eğitim Bilimleri Enstitüsü, Fen Eğitimi Programı, Konya.

Özaydın, T.C. (2010). İlköğretim yedinci sınıf fen ve teknoloji dersinde 5e öğrenme halkası ve bilimsel süreç becerileri doğrultusunda uygulanan etkinliklerin, öğrencilerin akademik başarıları, bilimsel süreç becerileri ve derse yönelik tutumlarına etkisi. (Yayımlanmamış doktora tezi). Ege Üniversitesi, Fen Bilimleri Enstitüsü, İzmir.

Özkan, B. (2001). Yapılandırmacı öğrenme ortamlarında özgün etkinlik ve materyal kullanımının etkililiği. (Yayımlanmamış doktora tezi). Hacettepe Üniversitesi, Sosyal Bilimler Enstitüsü, Ankara.

Özsevgeç, T. (2007). İlköğretim 5. sinıf kuvvet ve hareket ünitesine yönelik 5e öğretim modeline göre geliştirilen rehber materyallerin etkililiklerinin belirlenmesi. (Yayımlanmamış doktora tezi). Karadeniz Teknik Üniversitesi, Fen Bilimleri Enstitüsü, Trabzon.

Öztürk, Ç. (2008). Coğrafya öğretiminde 5e modelinin bilimsel süreç becerilerine, akademik başarıya ve tutuma etkisi. (Yayımlanmamış doktora tezi). Gazi Üniversitesi, Eğitim Bilimleri Enstitüsü, Ankara.

Peters, J. M. ve Stout, D. L. (2006). Methods for teaching elementary school science (5. Baskı). Ohio: Pearson Publishing.

Plourde, L. A., Alawiye O. (2003). Constructivism and elementary preservice science teacher preparation: knowledge to application. College Student Journal, September.

Rezba, R. J., Sprague, C., McDonnough, J. T. ve Matkins, J. J. (2007). Learning and assessing science process skills. New York: Kendall/Hunt Publishing Company.

Riesser S. T. (1994). Examination of reliability and validity of the performance assessmentof science skills (pass) instruments, alternative assessment instruments of science process skills. (Unpublished doctor's thesis). Ball State University, India. 
Sağlam, M. (2005). Işık ve ses ünitesi konusunda 5e modeline uygun rehber materyal geliştirilmesi ve etkililiğinin araştırılması. (Yayımlanmamış doktora tezi). Karadeniz Teknik Üniversitesi, Fen Bilimleri Enstitüsü, Trabzon.

Saygın, Ö. (2003). Lise 1 biyoloji dersi hücre konusunun öğretiminde yapılandırmacı yaklaşımın etkisi. (Yayımlanmamış yüksek lisans tezi). Gazi Üniversitesi, Eğitim Bilimleri Enstitüsü, Ankara.

Senemoğlu, N. (2009). Gelişim öğrenme ve öğretim. kuramdan uygulamaya. (14. basım). Ankara: Pegem Akademi.

Selcan, B. (2008). İlköğretim 7. sınıf fen ve teknoloji dersinde çevre konularının öğretiminde, yapılandırmacı yaklaşıma dayalı işbirlikli öğrenmenin öğrencilerin erişine etkisi. (Yayımlanmamış yüksek lisans tezi). Gazi Üniversitesi, Eğitim Bilimleri Enstitüsü, Fen Bilgisi Öğretmenliği Anabilim Dalı, Anakara.

Sevinç, E. (2008). 5E öğretim modelinin organik kimya laboratuvar dersinde uygulanmasının öğrencilerin kavramsal anlamalarına, bilimsel süreç becerilerinin gelişimine ve organik kimya laboratuvarı dersine karşı tutumlarına etkisi. (Yüksek lisans tezi). Gazi Üniversitesi, Kimya Bölümü, Kimya Eğitimi Anabilim Dalı, Ankara.

Smerdon, B. A., Burkam ve Lee, D. T. (1999). Access to costructivist and didactic teaching: who gets it? where is it practised? Teachers College Record, 101 (1), $5-34$.

Smith, D.W. (1997). Elementary students' use of science process skills in problem solving: the effects of an inquary-based instructional approach. (Yayımlanmamış doktora tezi). The Ohio State University, Ohio.

Solano-Flores, G. (2000). Teaching and assessing science process skills in physics: the bubbles task. Science Activities, 37 (1), 31-37.

Süzen, S. (2009). 5E ve geleneksel metotla işlenen fen ve teknoloji dersinin yapılandırılmış gridle değerlendirilmesi. Milli Ĕ̆itim Dergisi, 181, 169-183.

Şencan, H. (2005). Sosyal ve davranışsal ölçümlerde güvenilirlik ve geçerlilik. Ankara: Seçkin Yayıncılık.

Tabachnick, B.G. ve Fidell, L.S. (1996). Using multivariate statistics. (3. Bask1) New York: Harper Collins College Publishers.

Tatar, N. (2006). İlköğretim fen eğitiminde araştırmaya dayalı öğrenme yaklaşımının bilimsel süreç becerilerine, akademik başarıya ve tutuma etkisi. (Yayımlanmamış doktora tezi). Gazi Üniversitesi, Eğitim Bilimleri Enstitüsü, Ankara. 
5E Öğrenme Modeli'ne Göre Düzenlenmiş Eğitim Durumlarının Bilimsel Süreç Becerilerine Etkisi

Tinker, R. (1997). Thinking about science. (Elektronik Sürüm). Concord: The Concord Consortium Educational Technology Lab, M.A.

Trowbridge, L., Bybee, R.W ve Powell, J.C. (2004). Teaching secondary school science. New Jersey: Merrill / Prentice Hall.

Turpin, T. ve Cage, B. N., (2004). The effects of an integrated activity-based science curriculum on student achievement, science process skills and science attitudes. Electronic Journal of Literacy through Science, 3, 1-15.

Valentino, C. (2000). Developing science skills. Erişim: 20 Haziran 2010. http://www.eduplace.com/ science/profdev/articles/valentino2.html. 